\title{
Winning and Losing Democratic Elections: \\ Effects on Political and Social Attitudes and Subjective Well-Being
}

\author{
Dimiter Toshkov ${ }^{a 1} \&$ Honorata Mazepus ${ }^{\mathrm{b}}$ \\ ${ }^{a}$ Institute of Public Administration, Leiden University \\ ${ }^{b}$ Institute of Security and Global Affairs, Leiden University
}

This version: 14 December 2020

\begin{abstract}
In democracies, losing free and fair elections is a normal part of politics, and the consent of losers is needed for the survival of democratic government itself. But being on the losing side of the electoral contest can trigger important changes in the political and social attitudes, and even in the life outlook and subjective well-being of citizens. Based on individual-level survey data from 25 European countries and two time periods (2012 and 2018), we show that there is a significant gap between people who have voted for the parties in government and the losers of democratic elections when it comes to a wide set of political attitudes, including political trust, perceived efficacy and importance of government responsiveness and perceptions about how politics and government work. We also find that the gap between winners and losers extends to social trust, country attachment, feeling happy, healthy, safe, and optimistic, life satisfaction and perceived place in society. Most of these effects are greater in new democracies and for citizens with strong partisan attachments, some are bigger for men, and many are mediated by satisfaction with the government. Losing elections is hard for politics, but it could also be hard for the soul.
\end{abstract}

\section{Keywords}

democracy, elections, partisanship, political attitudes, social attitudes, voters, well-being

${ }^{1}$ Corresponding author: d.d.toshkov@,fgga.leidenuniv.nl 


\section{Introduction}

In democracies, losing free and fair elections is a normal part of politics, and the consent of losers is needed for the survival of democratic government itself (Anderson et al., 2005). But being on the winning or the losing side of elections can lead to important changes in attitudes of citizens towards democracy and the political game. Many studies document the existence of a winner-loser gap in satisfaction with democracy (inter alia Blais et al., 2017; Farrer \& Zingher, 2019; Loveless, 2020). While it is still unclear what changes open up the gap - whether it is winners increasing their satisfaction, or losers decreasing it, or both (Esaiasson, 2011; Hansen et al., 2019; van der Meer \& Steenvoorden, 2018), differences between election winners and losers are found across different empirical contexts and with different research designs, including panel survey data (Bol et al., 2018; Gärtner et al., 2020).

Some of the mechanisms that underpin the winner-loser gap in satisfaction with democracy are rather general. A winner effect has been extensively documented in sport competitions: winning leads to physiological reactions, such as increased levels of testosterone (Longman et al., 2018; McAuley et al., 1983; McCaul et al., 1992; Oliveira et al., 2009), which in their turn influence the psychological state and behavior of winners (Carré et al., 2013; Knight \& Mehta, 2014). In fact, the winner effect is found not only in humans but throughout the animal kingdom. Losing competitions can also have broad psychological and behavioral effects (Buser, 2016; Vongas \& Al Hajj, 2015).

Given the generality of these mechanisms, we hypothesize that the effects of winning or losing democratic elections should spill over to a variety of political and social attitudes, outlook on life and perceptions of well-being. The vast majority of existing literature has been focused on the winnerslosers gap in satisfaction with democracy in particular, with several studies analyzing political trust and efficacy as well (Anderson et al., 2005; Davis \& Hitt, 2016; Gärtner et al., 2020; Hooghe \& Stiers, 2016; van der Meer \& Steenvoorden, 2018). We propose that a much wider set of attitudes, beliefs and perceptions could be affected by winning and losing elections, including social trust, attachment to one's country, feelings of optimism, safety and hope, life satisfaction, perceived place in society, and more.

Synthesizing the existing literature on the winners-losers gap, we hypothesize that the effects of winning or losing on political perceptions, social attitudes, life outlook and well-being should be stronger for citizens with strong attachment to a political party (Plescia, 2019; Singh, 2014), mediated by satisfaction with the current government (Blais et al., 2017), and moderated at the individual level by gender (Williams et al., 2020) and at the country level by experience with democracy (Anderson \& Tverdova, 2001; Farrer \& Zingher, 2019; Linde \& Ekman, 2003) and the disproportionality of the 
electoral system (Anderson \& Guillory, 1997; Davis, 2014; Farrer \& Zingher, 2019; Hooghe \& Stiers, 2016), which exacerbates the impact of election wins and losses.

Empirically, we test these propositions using survey data on public opinion from two waves of the European Social Survey (ESS), fielded in 2012 and 2018, that cover 25 different countries and close to 100,000 respondents. We analyze the direct effect of election winner status, the mediating effect of satisfaction with government and the moderating effects of party attachment, gender, democracy age and disproportionality on 33 outcome variables using multilevel statistical models with fixed-effect demographic controls and random effects at the country level. In addition to these crosssectional analyses, we model the changes in attitudes of groups of voters that go in and out of government between 2018 and 2012: a design that addresses potential self-selection of winners and losers into parties with different likelihood of winning (which we operationalize as being part of the government coalition).

Our results show that a winners-losers gap exists for a large set of attitudes related to democracy and features of the democratic process, political trust, efficacy, activism and interest, expectations about government responsiveness, perceptions of how government and politics work in the country of the respondent, social trust, country attachment, perceptions of justice in the world, outlook on life, self-perceived health, happiness, life satisfaction and place in society. As expected, most of these effects are stronger for citizens with strong party attachments and are mediated by satisfaction with the government. We find evidence that many of the effects of winning on political attitudes and life outlook are stronger in new democracies, but very few significant moderating effects of electoral system disproportionality. There is mixed evidence for interaction effects of winning with gender, with some outcomes being strongly affected (e.g. satisfaction with democracy, optimism and happiness), while others not at all.

These results contribute to existing knowledge in a number of ways. First, we bring theories from different disciplines about the effects of winning and losing and we apply these ideas to the context of democratic elections. The hypotheses we identify lead us to significantly extend the empirical scope of the literature on the winners-losers gap by studying a much wider set of outcomes in the domains of the domains of socio-political life and individual wellbeing than done previously. Second, by showing that the effects of winning and losing possibly spill over from the domain of politics to general attitudes towards society, outlook on life and even (self-reported) health, happiness and life satisfaction, our study raises concerns about the general impact of losing elections on the wellbeing of citizens and democratic societies. While it remains to be studied how permanent the changes 
in attitudes induced by winning and losing are and how they translate into changes in behavior, our results uncover potentially important consequences of democratic elections that have until now remained hidden. Third, in terms of methodology our study introduces a new design for studying the winners-losers gap with repeated cross-sectional data that can address to some extent concerns about self-selection, thereby increasing confidence that the gap is produced by the effects of elections rather than pre-existing differences between voters of different parties.

\section{Literature review}

There is by now a large literature documenting the gap between winners and losers of elections with respect to satisfaction with democracy. The gap has been found in a variety of time periods, geographic areas and institutional contexts (Anderson et al., 2005; Blais et al., 2017; Farrer \& Zingher, 2019; Loveless, 2020). Remarkably, it might be greater for men compared to women (Williams et al., 2020).

\section{The gap between losers and winners of elections}

There is conflicting evidence whether the gap appears because winners experience an increase in satisfaction with democracy, or because losers experience a decrease, or both. An analysis of panel data in Denmark show that "turning from winning to losing has significant negative effects on voters' satisfaction" (Hansen et al., 2019). But according to a study using panel data from the Netherlands, the gap appears primarily because of a boost in satisfaction and political support among electoral winners, and to a lesser extent because of a drop in satisfaction and support among electoral losers, (van der Meer \& Steenvoorden, 2018) (note however that this study uses a rather wide definition of electoral winners - voting for parties that saw electoral gains). Analyzing a broader sample of countries, Esaiasson also concludes that 'winners typically become more supportive whereas losers at minimum retain their level of support from before the election' (Esaiasson, 2011). One of the few studies that does not find a gap between winners and losers (with respect to political trust, not satisfaction with democracy, however) actually observes that both winners and losers experience an increase in political trust right after elections in Belgium (Hooghe \& Stiers, 2016).

\section{Characteristics of winning and losing}

The type of a winner you are matters. The gap with losers is found to be greater with respect to 'optimal winners' rather than 'non-optimal winners' (Singh, 2014). Optimal winners are those who (a) voted for the party to which they were ideologically nearest, (b) liked the party they voted for best, 
and (c) felt closest to the party they voted for. A similar finding emerges when looking at voters for the winning party who voted 'with more confidence' (van der Meer \& Steenvoorden, 2018). Plescia also concludes that 'preferences for the supported party significantly moderate the effect of party performance on voter feelings' (Plescia, 2019).

Whether you are a persistent or occasional loser matters as well (Delgado, 2016), but if you are a persistent winner, being ideologically close to the government moderates the effect of winning: “Among present losers, previous experience of victory assuaged dissatisfaction, while among those presenting a consolidated 'winning' record, only high ideological proximity to the current government boosted political support." (Curini et al., 2012).

Winning as such is important, but the representation in government that it brings might be what really drives its effect on political attitudes. As Blais et al. (2017) put it: 'voting for parties that win more votes, more legislative seats, and more cabinet seats boosts satisfaction with democracy' (Blais et al., 2017). Whether the party you voted for ends up in government has been found to be the most important factor for satisfaction with democracy (Singh et al., 2012), stressing the importance of policy considerations.

The importance of ideological proximity and, even more so, policy congruence between voters and government for the winner-loser gap makes sense given the evidence that these are important factors predicting satisfaction with democracy more generally (Ferland, 2020; Stecker \& Tausendpfund, 2016). Data from Germany even suggest that "policy congruence with the government increases voters' democratic support whether they voted for the government or not" (Gärtner et al., 2020).

Most studies that look into the duration of the gap find that the effect is stable rather than short lived (Dahlberg \& Linde, 2017; Hansen et al., 2019; Loveless, 2020). The strength of the election effects peak shortly after the elections take place, and might even become apparent in the week before due to anticipation (Gärtner et al., 2020; van der Meer \& Steenvoorden, 2018). As more time passes after the election, the boost that winners experience wears off, while the attitudes of losers rebound (Davis \& Hitt, 2016). But a recent comparative study concludes that "both the levels of and the difference between satisfaction levels of "winners" and "losers" do not attenuate quickly but rather last almost 5 years' (Loveless, 2020). Analyzing data from Germany, however, (Gärtner et al., 2020) find only very small and short-lived effects of winning (note that the panel data they analyze has a very high dropout rate, which might bias against finding any effects if disappointed losers are more likely to drop from the survey). 
The type and context of election matters as well. Winning at local and regional elections produces effects at the national level, too (Blais \& Gélineau, 2007; Singh et al., 2012). Close elections increase the satisfaction of winners, but make no difference for the satisfaction of losers (Howell \& Justwan, 2013). More generally, election salience has been shown to increase the strength of party attachment and strengthen the link between party attachment and the evaluation of political actors (Singh \& Thornton, 2019).

\section{Systemic differences in the winner-loser gap}

There is evidence that the gap exists in old and new democracies alike (Anderson \& Tverdova, 2001; Fuchs et al., 1995). In countries that have recently transitioned to a democratic form of government, like the post-communist countries in Central and Eastern Europe, the gap in attitudes might be greater than in established democracies (Linde \& Ekman, 2003). But the effect of the proximity of democratic transition seems to vary on different continents: Farrer and Zingher find a negative effect in Europe, Asia and Latin America, but a positive one in Africa (Farrer \& Zingher, 2019). Other country-level characteristics might be important as well: Han and Chang find that 'satisfaction with democracy between electoral winners and losers widens as income inequality increases' (Han \& Chang, 2016).

Institutional features possibly moderate the effect of elections. For example, the proportionality of the electoral system has been found to decrease the winners-losers gap in Europe (Anderson \& Guillory, 1997; Davis, 2014; Hooghe \& Stiers, 2016), but Farrer and Zingher find no effects or even effects in the opposite direction on other continents (Farrer \& Zingher, 2019). There is limited research on the impact of more particular institutional features. Based on panel survey data from Belgium, Bol and coauthors concluded that 'casting a preference vote for a winning candidate [in a flexible-list PR system] makes little difference, as party-list voters are those with the largest increase in satisfaction with democracy' (Bol et al., 2018).

There are some documented effects of losing on political attitudes other than satisfaction with democracy. Several studies focus on political trust and external political efficacy as the outcome variable of interest (Anderson et al., 2005; Davis \& Hitt, 2016; Gärtner et al., 2020; Hooghe \& Stiers, 2016; Moehler, 2009; van der Meer \& Steenvoorden, 2018). Based on multiple-wave survey data from five referendums in Germany, Finland and the Netherlands, we learn that the losers of referendums decrease their support for referendums (Brummel, 2020). VanDusky-Allen finds a gap in the likelihood to protest between winners and losers in single party, majority systems, but not in coalition systems 
(VanDusky-Allen, 2017). Winners show higher assessment of the supply of freedoms, even in the context of weak democracies in Latin America (Monsiváis-Carrillo, 2020).

A related literature find a winners-losers gap with respect to support for democratic checks and balances and various accountability mechanisms (Berliner, 2020; Graham \& Svolik, 2020; Moehler, 2009; Singer, 2018). But with regard to these political attitudes, support among electoral losers increases rather than decreases.

\section{The effects of losing elections: theoretical expectations}

The review of existing studies makes it clear that the effects of winning and losing democratic elections on satisfaction with democracy and some related political attitudes are rather general, robust, and welldocumented. This is consistent with the idea that the effects are underpinned by some fundamental physiological processes shaped by evolution.

\section{Fundamental physiological and psychological mechanisms}

There is, in fact, a large literature that examines winners/losers effects in animals and in humans from an evolutionary perspective theoretically (for a review of evolutionary theoretical models, see (Mesterton-Gibbons et al., 2016)). For example, it has been established that 'winning can alter testosterone levels in men and that mood may mediate such changes' (McCaul et al., 1992). Longman et al. even show that testosterone increases after a 'victory' manipulated by the researchers, and that leads to heightened sociosexuality mediated by increased self-esteem (Longman et al., 2018). Elevated testosterone after winning also mediates future aggressive behavior in men (Carré et al., 2013). Oliveira et al. show testosterone increases following winning in women as well (Oliveira et al., 2009). Importantly, there is evidence that causal attribution (perceptions of what produced the winning situation and the controllability of the situation in particular) are important in shaping the affective reactions of winners (McAuley et al., 1983).

Most of this empirical evidence (at least, when humans are concerned) comes from sports competitions. But Stanton et al. analyse voters' testosterone responses in the aftermath of the 2008 US Presidential election and find that male voters for the winning candidate had stable testosterone levels after the election, while voters for the loosing candidates exhibited drops in testosterone levels 
(Stanton et al., 2009)2. The conclusion is that 'male voters exhibit biological responses to the realignment of a country's dominance hierarchy'. Overall, there is increasing evidence for a reciprocal relationship between hormones and hierarchical status: for an overview, see (Knight \& Mehta, 2014).

Another mechanism for the effects of losing elections comes from the field of coalition psychology - the study of the motivations developed throughout human evolution that affect human capacity for collective action. Elections provide a cue about what the winning coalition in society is. Through elections, individuals learn whether they are in the majority or minority, whether they lost or gained control over distribution of resources, and whether their social position improved or worsened - information that can affect fundamental processes related to coalitional psychology (Boyer et al., 2015). Being a part of losing coalition can have serious physiological effects. As coalitional threat is a recurring problem in human environment, humans, like other mammals, have evolved neurophysiological responses to such direct challenges (Gunnar \& Quevedo, 2006). In humans, being in a losing coalition can result in the release of epinephrine (adrenaline) or cortisol (stress hormone) and if experienced repeatedly, negatively affect health and wellbeing (Sapolsky 2007).

If the mechanisms underpinning winner and loser effects are so fundamental, affecting physiological processes and psychological states such as emotions, we would expect that the effects of winning or losing elections spill over from the domain of political attitudes to other, more general, social attitudes and even to subjective well-being and health ${ }^{3}$. In other words, we should observe such effects beyond the narrow set of political attitudes examined in the literature so far. In the remainder of this section, we take up this insight and develop concrete hypotheses that can be tested empirically. We identify these hypotheses by building on the existing political science research, and we use them to structure the empirical analyses. But our research goals remain primarily exploratory rather than theory-testing, which would be premature given the lack of a general integrated theory.

\section{Winners-losers effects on political attitudes and perceptions}

We are on firmest ground when we consider the winners/losers effects with regard to satisfaction with democracy. Even if the exact mechanisms behind this effect remain a subject of some debate (see above),

\footnotetext{
${ }^{2}$ For studies of the impact of emotions in politics, see (Valentino et al., 2011) who focus on the effect of anger on political mobilization and the special issue edited by (Petersen et al., 2020) on the role of disgust.

3 After the 2016 US Presidential elections, 'there were 54.6 million more days of poor mental health among adults in December 2016, the month following the election, compared to October 2016' in the states that voted for the losing candidate' (Yan et al., 2020). The authors of this study conclude that 'elections could cause at least transitory increases in poor mental health'.
} 
we expect winners and losers of elections to exhibit a detectable gap in their levels of satisfaction with democracy. The same expectation holds for the related concepts of democracy importance and the evaluation of democracy as a form of governance.

We also hypothesize that there will be a winners-losers gap with respect to the perceived political efficacy of citizens (cf. Anderson \& Tverdova, 2001; Davis, 2014; Davis \& Hitt, 2016; van der Meer \& Steenvoorden, 2018). We conceptualize political efficacy as the belief that someone can influence and participate in politics. Losing elections should decrease the perceived ability of citizens to do that.

A similar logic leads us to anticipate a gap in political trust (which includes trust in political parties, politicians, and the national parliament) (Hooghe \& Stiers, 2016; van der Meer \& Steenvoorden, 2018). Changes in political trust can spillover to affect changes in trust in institutions of the state as well, such as the legal system and the police. Since these institutions are at least to some extent independent from politics and the changing colors of the government, the effects might be smaller. Nevertheless, they could still be present to the extent that people associate state institutions with the politicians in power.

It is more difficult to hypothesize a directional effect of winning or losing on political activism (cf. VanDusky-Allen, 2017). On the one hand, losing elections can demotivate people by increasing feelings of ineffectiveness of one's efforts, beliefs that the 'game is rigged' and the costs of political action are not worth it. On the other hand, losing can have the opposite effect as well, motivating increased efforts to resist the new government by political actions. And winning can induce complacency among the winners as well.

Similarly, interest in politics and consumption of political news could be affected in a number of ways from the results of an election. Losing can trigger decline in political interest and news consumption: why pay attention to a game your team keeps losing? Conversely, losing might lead people to pay more attention to politics and political news because they have to scrutinize closer a government they opposed at the voting booths. By that logic, it is election winners who can afford to drop their level of attention to politics, because their team is in power now.

Partisanship can affect satisfaction with particular policies, such as the economy, health and education. While assessment of public policies affect party choice as well, people judge policy outcomes and developments through a lens that is heavily tinted by partisanship. As a consequence, a gap between winners and losers should appear as well. 
Winners and losers of elections could have differential perceptions of the way the government operates (e.g. with regard to transparency) and that it works for all people (impartiality), with losers perceiving the government as less transparent and more partial.

When it comes to different features of democratic regimes, however, our expectations diverge. For the importance of free and fair elections, we hypothesize that election winners score higher: after all, they just benefited from this feature of the political process. For the importance of checks and balances, we hypothesize that election losers will score higher: this is because the losers of the current elections need these checks and balances to limit the power of the government they do not support and to guarantee a fair political process until the next elections (Berliner, 2020; Singer, 2018). The same expectation holds for the freedom to express extreme political views. Those who have not voted for the current government can be expected to be more vigilant in protecting pluralism in society.

Winners of elections are more likely to support the importance of government responsiveness: government taking into account to view of the majority when making policy. Having established at the election that a majority supports their views, election winners can only gain from strong government responsiveness. To the contrary, losers, who find themselves in the minority, should find government responsiveness to majority views less important.

While the expectations above refer mostly to the perceived importance of different features of democratic governance and politics, the perceptions of how these features work in the country of reference should be affected as well. Winners can judge the importance of checks and balances and freedoms to express extreme views lower than losers do. But winners will still perceive that the country is having sufficient checks and balances and protection of political freedoms to a greater extent than losers.

\section{Winners-losers effects on social attitudes and subjective well-being}

The hypotheses above refer to a large set of political attitudes, evaluations and perceptions. But, as argued in the beginning of this section, there are good reasons to expect that the winners-losers effects does not stop at the border of political domain. Given that political attitudes are tightly linked to more general social predispositions, it is natural to expect that effects spill over.

The most direct extension is to interpersonal trust. Losing at election makes people realize that a majority of the people in the country do not share their views and preferences. Similarly to the expectations about political and institutional trust, we hypothesize that election losers will exhibit systematically lower interpersonal trust than election winners. A related argument can be made about election losers decreasing their feeling of attachment to their country. 
Losing can also affect feelings of optimism about your own future, the state of society and the future of the world. Getting a party you did not support to form a government and rule until the next elections at least means that your hopes for desired policy reforms would not materialize; moreover, you realize that these hopes are not shared by a majority of the people in the country. Similarly, losing elections can increase perceptions of unfairness in the world.

Such feelings and perceptions can generalize to the overall well-being of people. Losing can increase feelings of safety (both directly because you know that most people do not share your views and indirectly via ineffective government actions to ensure safety). Losing can also negatively affect (perceived) health via the physiological effects it has on the body, promoting stress, aggression and anxiety (Yan et al., 2020).

Ultimately, a gap between winners and losers of election can appear with regard to feelings of happiness, life satisfaction and perceived place in society. Losing means that your political and policy goals are not going to be realized. To the extent that one cares about political and policy goals, this should lead to a downwards correction in your perceptions of your place in society and personal fulfillment.

\section{The mediating role of satisfaction with the government}

As discussed in the literature review, it is plausible that the political effects at least are mediated by satisfaction with the current government (cf. Blais et al., 2017). That is, satisfaction with democracy, perceived efficacy, trust, and so on decrease for losers and/or increase for winners because elections produce governments that make policies for and represent better the winners rather than the losers. The mediating role of satisfaction with the government relies on a more rational mechanism than affect generated from losing as such. That is why, we expect that satisfaction with the government will translate a larger part of the winner-loser effects on political outcomes and a smaller part of the effects on social outcomes and well-being.

\section{Individual moderators: types of winners and gender}

At the individual level, we hypothesize that the winners-losers gap will be greater for citizens with more political engagement and allegiance to political parties (Plescia, 2019; Singh, 2014). The effects should be most visible among the subset of citizens who feel very strongly attached to a political party, less so for people who have voted, and even less so in the general population, which includes non-voters as well. 
To the extent that the winners-losers gap is spurred by changes in testosterone levels, we can expect that the effects will be moderated by gender (Williams et al., 2020) and will be stronger among men compared to women.

\section{Country-level moderators: new and old democracies and electoral systems}

At the country level, these effects should be stronger for new democracies (and non-democracies) (Anderson \& Tverdova, 2001; Farrer \& Zingher, 2019; Fuchs et al., 1995; Linde \& Ekman, 2003). In established democracies citizens have experienced multiple changes of parties in government and are less likely to perceive an election loss as an irreversible change.

Finally, in line with existing literature, we expect that the effects should be stronger in majoritarian democracies and more disproportional electoral systems rather than systems based on proportional representation (Anderson \& Guillory, 1997; Davis, 2014; Farrer \& Zingher, 2019; Hooghe \& Stiers, 2016). Majoritarian systems produce more clear winners and losers from elections (Plescia, 2019). In addition, winners get more direct and unconstrained access to government. In proportional systems, multiple parties can be perceived as winners and losers based on their relative gains. Furthermore, coalition governments being the norm, it is harder for citizens to attribute both blame and credit for policies to individual parties. So the level of proportionality of the political system should moderate the size of the winners-losers gap. 


\section{Research design, data and method of analysis}

We test the hypotheses identified above on comparative survey data of public opinions and attitudes for a large number of European states. In particular, we use two waves of the European Social Survey ${ }^{4}$ Wave 6 (2012) and Wave 9 (2018), which feature a number of relevant outcome variables for our study ${ }^{5}$. Some of these variables are measured in both waves of the survey and others only in one. We chose the 2012 wave because it features an additional extended module on political attitudes and the 2018 wave because it is the most recent available. Importantly, in addition to analyzing the crosssectional data from both survey waves, we perform a second set of analyses in which we compare the changes in the attitudes of supporters of different parties when they go in and out of power between the two waves of the survey.

Table 1 presents an overview of the data availability for the outcome variables of interest. The exact wording for all variables is available in the Supplementary Material. The country-level moderator disproportionality is measured with the Gallagher index (Gallagher, 1991) ${ }^{6}$. We classify the postcommunist countries from Central and Eastern Europe (including the Balkans) as new democracies.

We identify winners and losers of elections by matching the reported vote choice of the respondent at the latest national elections to the parties in government at the moment of collecting the survey information. We include those who voted for any of the parties in the governing coalition, however small, as winners and the rest as losers. Hence, we do not focus on relative electoral gains compared to previous periods nor on the absolute size of the vote share of each party as such, but only on whether the party ended up in government or not (cf. Gärtner et al., 2020; Singh, 2014; Stiers et al., 2018).

As explained in the theoretical section, we also employ more narrow definitions of who are electoral winners and losers than all 'citizens'. 'Voters' restricts the sample to people who have voted for any party at the latest elections; thus, excluding non-voters. 'Partisans' restricts the sample to people who feel close or very close to at least one of the parties competing at the latest national elections; thus, excluding citizens who do not feel close to any party, even if they have voted for one.

\footnotetext{
4 The European Social Survey provides high-quality nationally-representative samples for the population of the countries included in the study (the exact set of participating countries differs from wave to wave). The interviews are conducted in person and the national surveys achieve very high response rates.

5 We use the essurvey package for R to obtain the data (Cimentada, 2019).

${ }^{6}$ The data is obtained via http://christophergandrud.github.io/Disproportionality Data/.
} 
Table 1. Overview of the outcome variables and data availability

\begin{tabular}{|c|c|c|}
\hline Label & Variable & Year \\
\hline sat.democracy & Satisfaction with democracy & $2012 ; 2018$ \\
\hline dem.evaluation & Evaluation of democracy & 2012 \\
\hline imp.democracy & Importance of democracy & 2012 \\
\hline imp.fair.elections & Importance of free and fair elections & 2012 \\
\hline imp.dem.checks & $\begin{array}{l}\text { Importance of checks and balances [index from } 3 \\
\text { variables] }\end{array}$ & 2012 \\
\hline imp.free.extreme.views & Importance of freedom to express extreme views & 2012 \\
\hline pol.efficacy & Political efficacy [index from 5 variables] & 2018 \\
\hline political.trust & Political trust [index from 3 variables] & $2012 ; 2018$ \\
\hline trust.extra & $\begin{array}{l}\text { Trust in the legal system and police [index from } 2 \\
\text { variables] }\end{array}$ & $2012 ; 2018$ \\
\hline pol.activism & Political activism [index from 6 variables] & $2012 ; 2018$ \\
\hline pol.interest & Political interest & $2012 ; 2018$ \\
\hline pol.news & Political news consumption & 2012,2018 \\
\hline sat.policy & Policy satisfaction [index from 3 variables] & $2012 ; 2018$ \\
\hline pol.transparent & Perception of government transparency & 2018 \\
\hline gov.works.for.all & Perception that government works for all & 2018 \\
\hline imp.gov.responds & Importance of government responsiveness & 2012 \\
\hline fair.elections.in.country & Perception of free elections in country & 2012 \\
\hline dem.checks.in.country & Perception of opposition and media rights in country & 2012 \\
\hline gov.punished.in.country & $\begin{array}{l}\text { Perception of governments punished in elections in } \\
\text { country }\end{array}$ & 2012 \\
\hline gov.explains.in.country & Perception that government explains in country & 2012 \\
\hline gov.responds.in.country & Perception of government responsiveness in country & 2012 \\
\hline free.extreme.views.in.country & Perception of freedom of extreme views in country & 2012 \\
\hline social.trust & Interpersonal trust & $2012 ; 2018$ \\
\hline feel.country.attached & Feeling attached to country & 2018 \\
\hline justice.prevails & Justice will eventually prevail & 2018 \\
\hline feel.pessimistic & Feeling (not) optimistic about own future & 2012 \\
\hline life.gets.better & Feeling life gets worse for most people & 2012 \\
\hline feel.hopefull & Feeling hopeless for future of the world & 2012 \\
\hline feel.unsafe & Feeling safe & $2012 ; 2018$ \\
\hline feel.unhealthy & Feeling (un)healthy & $2012 ; 2018$ \\
\hline feel.happy & Feeling happy & $2012 ; 2018$ \\
\hline life.satisfaction & Life satisfaction & $2012 ; 2018$ \\
\hline place.in.society & Place in society & 2012 \\
\hline
\end{tabular}

\section{Method of analysis}

We model the outcome variables of interest with multilevel (mixed-effects) linear regression models. We combine both waves of the survey data in a single pooled dataset. The baseline models include demographic controls (gender, age 7 , education and occupation) as fixed effects, and country intercepts and slopes for the main effect of interest as random effects. We model each outcome variable

${ }^{7}$ For a comprehensive analysis of the relationship of age with satisfaction with democracy, see (Wuttke et al., 2020) 
separately. This is because we are not interested in the impact of the winner-loser status on, say, satisfaction with democracy, conditional on the respondents evaluation of democracy and other attitudes $^{8}$.

To test the moderating effect of different types of winners, we estimate all models for three groups of respondents: citizens, voters, and partisans. To test the moderating effects of gender, new democracy and proportionality, we include interactions of these variables with the winner-loser status (again, we enter the interactions one by one rather than all at the same time to ease interpretation). To test the mediating effect of satisfaction with the government, we report a set of models in which this variable is included in the list of covariates, and we compare these models to the ones without the variable. We also conduct causal mediation analyses to estimate the direct and indirect (via satisfaction with government) effects of winner-loser status (Imai et al., 2010; Tingley et al., 2014), and we report those in the Supplementary Material.

In addition to these cross-sectional analyses, we employ an alternative modeling strategy that includes a temporal component as well. To do that, we track the groups of citizens who voted for a winning party in 2012 but not in 2018, and those who were on the losing side in 2012 but on the winning one in 2018. (Note that this is a not a repeated measures panel setup since the individuals in the two time periods of the survey are not the same). By comparing whether the attitudes of the different groups of voters 'flip' depending on whether they are in government or not, we bring additional evidence whether the gap in attitudes between winners and losers is causally driven by the fact of winning or losing at the elections or by pre-existing differences in the groups voting for winning and losing parties.

In the main text of this article, we present most of the regression model results only graphically. Full details are available in an interactive app, which allows the user to select the outcome variable, covariates, and interaction effects of interest, as well as subset the data to different subpopulations. The app is available at: https://dimiter.shinyapps.io/election_winners_effects/.

\footnotetext{
${ }^{8}$ Models with random effects at the level of the year/survey wave are reported in the Supplementary Material.
} 


\section{Empirical results}

\section{Part I. The direct effect of winner status}

We start the presentation of the empirical results by showing in Table $2^{9}$ the summary of the multilevel regression output for four outcome variables from the entire set of 33. These baseline models feature the main variable of interest - winner status, as well as age, gender, education and employment as individual-level fixed effects, new/old democracy as a country-level fixed effect, random intercepts for country, and random slopes for the effect of winner status by country. In this table and all graphs that follow, the outcome variables have been scaled to have a mean of 0 (centered) and a standard deviation of 1 (standardized). Hence, the size of the effects of the covariates is directly comparable across the different outcome variables. The models in Table 2 are estimated on all respondents for which there is valid information on these variables ('citizens') in the combined dataset.

Table 2. Multilevel regression results for four outcome variables of interest

\begin{tabular}{|c|c|c|c|c|c|c|c|c|c|c|c|c|}
\hline \multirow{3}{*}{$\frac{\text { Predictors }}{\text { (Intercept) }}$} & \multirow{2}{*}{\multicolumn{3}{|c|}{$\begin{array}{l}\text { sat.democracy } \\
\text { Estimates Std. error P-value }\end{array}$}} & \multirow{2}{*}{\multicolumn{3}{|c|}{$\begin{array}{l}\text { imp.dem.checks } \\
\text { Estimates Std. error P-value }\end{array}$}} & \multirow{2}{*}{\multicolumn{3}{|c|}{$\begin{array}{l}\text { social.trust } \\
\text { Estimates Std. error P-value }\end{array}$}} & \multirow{2}{*}{\multicolumn{3}{|c|}{$\begin{array}{l}\text { life.satisfaction } \\
\text { Estimates Std. error P-value }\end{array}$}} \\
\hline & & & & & & & & & & & & \\
\hline & -0.65 & 0.09 & $<0.001$ & -0.57 & 0.07 & $<0.001$ & -0.80 & 0.08 & $<0.001$ & -0.66 & 0.07 & $<0.001$ \\
\hline Age & 0.00 & 0.00 & $<0.001$ & 0.00 & 0.00 & $<0.001$ & 0.00 & 0.00 & $<0.001$ & 0.00 & 0.00 & $<0.001$ \\
\hline Gender (male) & 0.03 & 0.01 & $<0.001$ & 0.15 & 0.01 & $<0.001$ & 0.02 & 0.01 & $<0.001$ & -0.02 & 0.01 & 0.01 \\
\hline Education (years of) & 0.03 & 0.00 & $<0.001$ & 0.10 & 0.00 & $<0.001$ & 0.08 & 0.00 & $<0.001$ & 0.05 & 0.00 & $<0.001$ \\
\hline Employed in paid work & 0.05 & 0.01 & $<0.001$ & 0.06 & 0.01 & $<0.001$ & 0.08 & 0.01 & $<0.001$ & 0.19 & 0.01 & $<0.001$ \\
\hline Employed: studying & 0.37 & 0.01 & $<0.001$ & -0.02 & 0.02 & 0.43 & 0.29 & 0.01 & $<0.001$ & 0.51 & 0.01 & $<0.001$ \\
\hline Old democracy & 0.50 & 0.11 & $<0.001$ & -0.05 & 0.09 & 0.54 & 0.49 & 0.11 & $<0.001$ & 0.45 & 0.10 & $<0.001$ \\
\hline Winner status & 0.38 & 0.04 & $<0.001$ & 0.01 & 0.02 & 0.82 & 0.09 & 0.01 & $<0.001$ & 0.14 & 0.02 & $<0.001$ \\
\hline \multicolumn{13}{|l|}{ Random Effects } \\
\hline$\sigma^{2}$ & \multicolumn{3}{|l|}{0.77} & \multicolumn{3}{|l|}{0.92} & \multicolumn{3}{|l|}{0.83} & \multicolumn{3}{|l|}{0.82} \\
\hline$\tau_{00}$ & \multicolumn{3}{|c|}{0.13 country } & \multicolumn{3}{|c|}{0.05 country } & \multicolumn{3}{|c|}{0.09 country } & \multicolumn{3}{|c|}{0.08 country } \\
\hline$\tau_{11}$ & \multicolumn{3}{|c|}{0.05 country: winner status } & \multicolumn{3}{|c|}{0.01 country: winner status } & \multicolumn{3}{|c|}{0.00 country: winner status } & \multicolumn{3}{|c|}{0.01 country: winner status } \\
\hline$\varrho 01$ & \multicolumn{3}{|c|}{-0.52 country } & \multicolumn{3}{|c|}{-0.26 country } & \multicolumn{3}{|c|}{0.08 country } & \multicolumn{3}{|c|}{-0.36 country } \\
\hline $\mathrm{ICC}$ & \multicolumn{3}{|l|}{0.14} & \multicolumn{3}{|l|}{0.05} & \multicolumn{3}{|l|}{0.10} & \multicolumn{3}{|l|}{0.09} \\
\hline $\mathrm{N}$ & \multicolumn{3}{|c|}{31 country } & \multicolumn{3}{|c|}{26 country } & \multicolumn{3}{|c|}{31 country } & \multicolumn{3}{|c|}{31 country } \\
\hline Observations & \multicolumn{3}{|c|}{87404} & \multicolumn{3}{|c|}{46852} & \multicolumn{3}{|c|}{90503} & 90331 & & \\
\hline Marginal R² / Conditional R² & 0.105 & 0.228 & & 0.043 & 0.092 & & 0.085 & 0.179 & & 0.081 & 0.165 & \\
\hline
\end{tabular}

\footnotetext{
${ }_{9}$ We use the sjPlot package for $\mathrm{R}$ for the model summaries (Lüdecke, 2018).
} 
Table 2 displays information about the fixed effects (coefficients, standard errors and statistical significance) and the random effects from the models ${ }^{10}$, as well as measures of model fit. According to the information in the table, the effect of winner status is positive and highly statistically significant on satisfaction with democracy, social trust, and life satisfaction, but not on the importance of democratic checks and balances, in line with our hypotheses.

A relatively large part of the variance is accounted for by the random country intercepts $\left(\tau_{00}\right)$ : greatest in the case of satisfaction with democracy and smallest in the case of importance of democratic checks and balances. The random slopes for the effect of winner status $\left(\tau_{11}\right)$ are related to relatively large part of the variance in the case of satisfaction with democracy, but much smaller ones for the other three outcome variables. Altogether, the grouping structure in the data (at the country level) explains $14 \%$ of the variance in the case of satisfaction with democracy and only $5 \%$ in the case of the importance of democratic checks and balances (see the row in the table reporting the intraclass correlation coefficient, ICC). In all models with the exception of social trust, there is significant negative correlation ( $\left.\varrho_{01}\right)$ between the country intercepts and slopes, meaning that the higher the value of the country intercept (higher values of satisfaction with democracy, etc.), the lower the effect of winner status in that country, relative to the average effects of winner status in the entire sample. Note that the model for the importance of democratic checks and balances has a smaller number of observations because the outcome variable is measured in only one of the survey waves.

While Table 2 presents detailed information about the models, we only focus on the effect of winner status in reporting the analyses of the remaining outcome variables of interest. We summarize these effects graphically by plotting the estimated coefficient and 95\% confidence intervals for each outcome variable. Figure 1 shows the effects for three groups of respondents: citizens, voters (those who voted in the last national election) and partisans (respondents who feel close or very close to one of the political parties in the country). These estimates are obtained from models analogous to the ones reported in Table 2 in terms of structure and included covariates; details are available at the accompanying interactive app: https://dimiter.shinyapps.io/election_winners_effects/.

As we can see from Figure 1, for almost all outcome variables, the effect of winner status is significant (the $95 \%$ confidence interval does not overlap with zero) and in the hypothesized direction.

\footnotetext{
10 The models have been estimated with the Ime4 (version 1.1-23) (Bates et al., 2015) package in $R$ (version 4.0.2). The model summaries are obtained with the sjPlot (version 2.8.6) package. According to the documentation, 'the marginal Rsquared considers only the variance of the fixed effects, while the conditional R-squared takes both the fixed and random effects into account. The $\mathrm{p}$-value is a simple approximation, based on the t-statistics and using the normal distribution function.'
} 
With regard to attitudes towards democracy, the positive effect of voting for the winning party is greatest for satisfaction with democracy, smaller for evaluation of democracy and smallest (but still positive) for the perceived importance of democracy. From the list of democracy features, there is a positive effect on the importance of fair elections, but a negative effect (among voters and partisans) on the importance of democratic checks and balances. The effect on the importance of the freedom of expressing extreme views is possibly negative, but is not estimated precisely.

\section{Coefficients and $\mathbf{9 5 \%}$ confidence intervals for the effects of voting for a winning party among citizens, voters, and partisans}

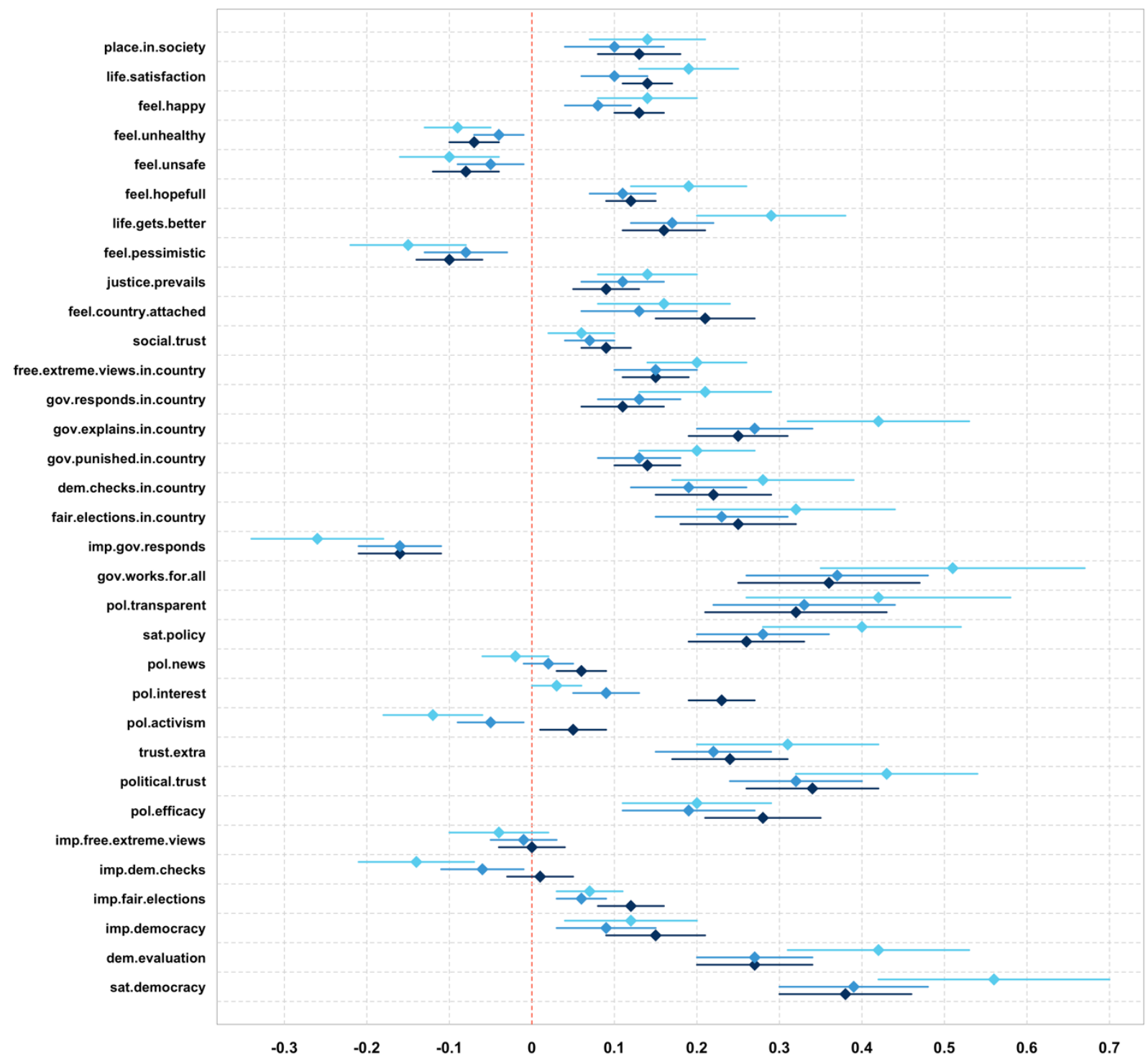

Figure 1. Coefficients and 95\% confidence intervals for the effects of voting for a winning party among citizens, voters, and partisans 
There are large positive effects on perceived political efficacy, trust in political institutions and trust in the legal system and the police (trust.extra). Interestingly, when it comes to political activism, the effect is positive in the full sample, but turns negative when we consider partisans only. Political interest increases most significantly in the full sample, and much less so for partisans. There are no significant differences between winners and losers when it comes to the consumption of political news in the subsamples of partisans and voters, but a small positive effect of winning in the full sample.

The effects on satisfaction with policy (the state of the economy, education, and health) are large and positive, as are perceptions that politics works in a transparent way and that the government works for all. Interestingly, however, election winners are much less likely to consider that the government should always take the opinions of the citizens into account when making policy (imp.gov.responds). This effect is not in the direction we hypothesized. Presumably, for election winners it is more important that the government implements its program and fulfils its electoral pledges despite what the public might think about such reforms.

Election winners are much more likely to perceive that in their own country elections are free and fair, media and opposition rights are respected (note the difference with the item on how important these democratic checks and balances are), extreme views can be freely expressed, the government responds to the citizens, explains its decisions, and is punished for bad performance at elections.

Looking beyond the domain of political attitudes, we find large and significant differences between voters for the winning party and the rest of the citizens on social trust and country attachment. Election winners are more likely to agree that justice eventually prevails and life gets better and are less likely to feel pessimistic about their own lives. They are more likely to feel hopeful, safe and healthy. Finally, elections winners have higher self-reported happiness, life satisfaction and consider themselves at a higher position in the social ladder.

Importantly, the vast majority of these inferences do not change depending on whether we consider the full sample, voters, or partisans only. This implies that the differences between winners and losers are not driven primarily by the subset of people who do not vote at elections and are not interested in politics. While, overall, the effects remain significant across the different specifications of the sample, in some cases, there are substantively interesting differences in the size of the effects. For example, the positive effect of satisfaction with and evaluation of democracy is much greater among partisans than among citizens and voters. Conversely, the jump in perceived political efficacy is smaller for voters and partisans then in the full sample. The differences with respect to the 
importance of democratic checks and balances, political interest and activism were noted above. Altogether, for political attitudes the effects of winner status are more pronounced among partisans, despite the much smaller samples from which they are estimated (there are 29830 partisans, 66005 voters, and 92272 citizens in the combined dataset from the two survey waves). The picture is similar with respect to social attitude and well-being, with the largest differences between partisans and citizens with respect to outlook on life (life gets better, feeling hopeful, feeling pessimistic).

The models above feature a small set of covariates - age, gender, education, occupation and new/old democracy, as well as random slopes and intercepts at the country level. But there is one additional possible confounder that might account for the relationships we see in Figure 1: political ideology. It is reasonable to expect that citizens with more extreme ideological positions will be less satisfied with democracy, exhibit lower political and social trust, positive perceptions about how the government and democracy work, life satisfaction, and so on. Citizens with more extreme ideological positions would be more likely to be election losers as well, in most democratic countries. These arguments speak in favour of including the left/right position and its extremity (the absolute value of the deviance from the mean of the scale) as covariates in the models. However, it is also plausible that losing elections shifts the self-reported ideology of citizens away from the center, and in that case we would not want to control for ideology. Moreover, $15 \%$ of citizens, $10 \%$ of voters and $5 \%$ of partisans have missing data on their ideological self-placement, which might introduce selection bias.

Nevertheless, to explore the robustness of the results presented in Figure 1, we re-estimate the models including the absolute left-right position and extremity as covariates. Figure 2 summarizes the results of these models in columns 4 to 6 . The left panel of the figure (columns 1 to 9) shows the sign of the effect (positive or negative) of voting for the winning party and its statistical significance, which is colour coded for three sets of models, each estimated for all citizens (c), voters (v) and partisans (p). The first three columns show the same information as Figure 1. The size of the positive and negative signs in the figure are proportional to the effect sizes of the regression coefficients.

The models with left-right position and extremity included in the set of covariates do not lead to major changes: all effects retain their significance and in some case (political interest, importance of democratic checks and balances) are even estimated more precisely. 


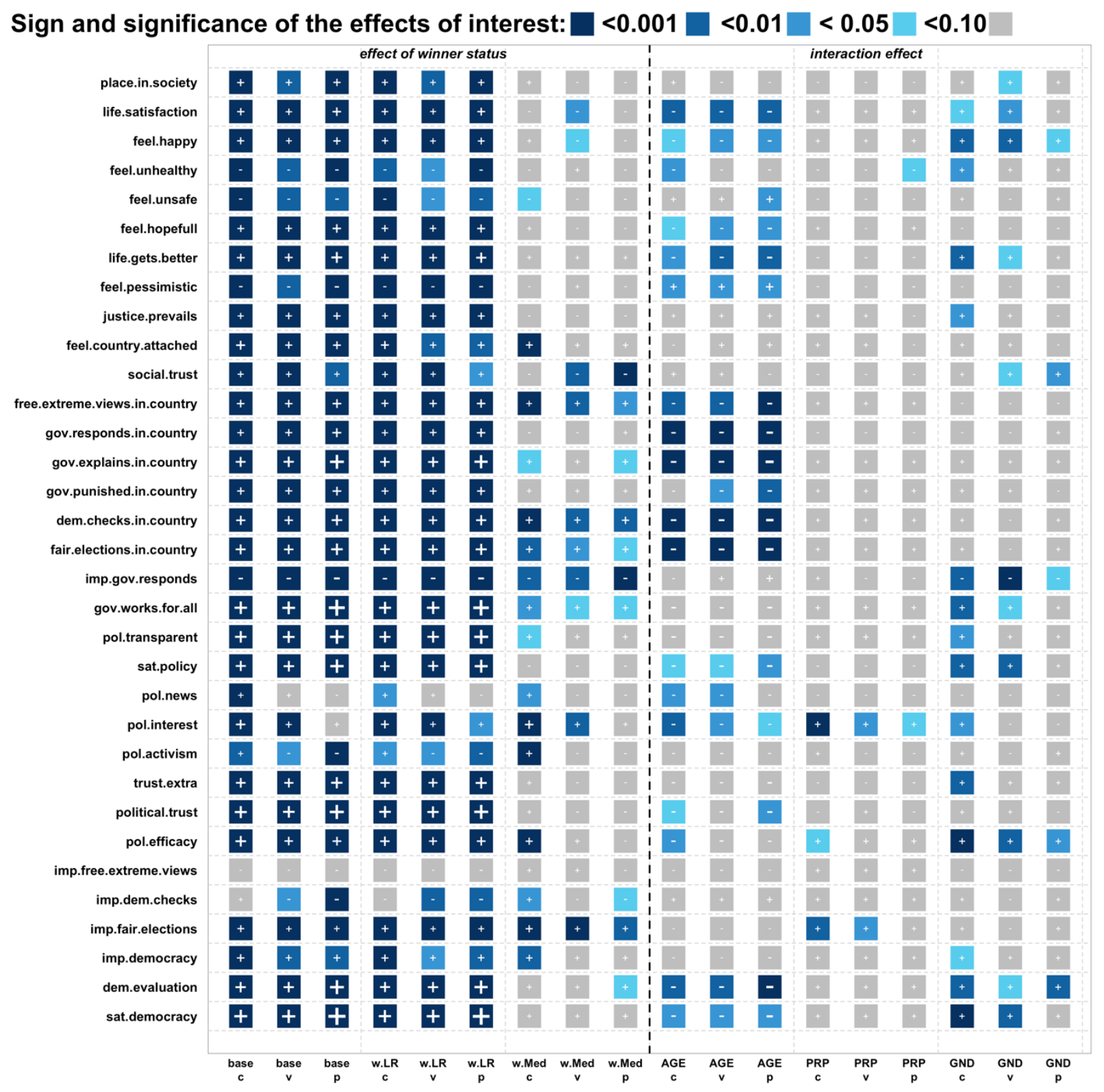

Figure 2. Sign and colour-coded statistical significance of the effects of voting for a winning party (left panel: columns 1 to 9) and of the interaction between voting for a winning party and three possible moderators (right panel: columns 10 to 18). Size of effects is proportional to size of the sign in its square Abbreviations: base-baseline model; w.LR-baseline model with the addition of left-right position and extremity; w.Med-baseline model with the addition of satisfaction with government (mediator); AGE-with new/old democracy interaction [new is baseline]; PRP-with disproportionality interaction; GDN-with gender interaction (sign. of interaction) [female is baseline]; c-citizens; v-voters; p-partisans 


\section{Part II. The mediating role of satisfaction with the government}

The analysis so far focused on the direct main effect of winner status. Now we turn towards examining the possibly mediating role of satisfaction with the government. To do so we re-estimate the baseline models including satisfaction with the government as a covariate. If this variable plays a mediating role, we would expect that the coefficients of winner status become smaller and cannot be distinguished from zero.

The results of these models are summarized in columns 7 to 9 in Figure 2 (see also the causal mediation models reported in the Supplementary Material, which lead to the same conclusions). As we can see, the effects of winner status on most of the outcome variables disappear completely or get reduced substantially. Some notable exceptions are political interest, the importance of fair elections and the perceptions about how democracy works and the government functions in the country of respondent. Interestingly, conditional on satisfaction with democracy, the effect on social trust turns negative, and significantly so for the subsets of voters and partisans. The negative association between political news consumption and winner status gains statistical significance once satisfaction with the government is included. What is noteworthy as well is that satisfaction with the government appears to mediate the effects of winning on well-being as well. This implies that, after all, it is not winning as such that matters but being represented by a government that you feel satisfied with.

\section{Part III. Moderating effects of democracy age, disproportionality and gender}

Next, we turn to assessing the hypotheses about the moderating role of democracy's age, the disproportionality of the electoral system and the gender of the individual. These hypotheses require that we test interaction effects between these three variables and winner status. Given the limited number of observations at the country level, we enter the interactions separately to the baseline models.

The results of these models are summarized in the right panel of Figure 2 (columns 9 to 18) which focus on the sign and significance of the interaction effects. The effect of winning at elections differs significantly in new and old democracies when it comes to satisfaction with and evaluation of democracy, political trust, political interest, consumption of political news, satisfaction with policy, and all evaluations of how democracy and government work in the respondent's country. The negative sign of the interaction implies that the effect of winning is stronger in new democracies, which are the baseline category in these models. In other words, election winners get a greater boost on all these political attitudes from winning in political systems that have recently transitioned to democracy. 
The differences in the effect of winning are not significant across old and new democracies when it comes to social attitudes, but they are for well-being. The winner-loser gap in life satisfaction, feelings of happiness, safety and optimism is significantly smaller in old, established democracies than in new ones. To illustrate the substantive size of the differences across new and old democracies, Figure 3 shows the winner status coefficients and associated $95 \%$ confidence intervals for the two sets of countries based on the estimates from the multilevel models.

\section{Coefficients and $95 \%$ confidence intervals for the effects of voting for a winning party for partisans in new and old democracies:}

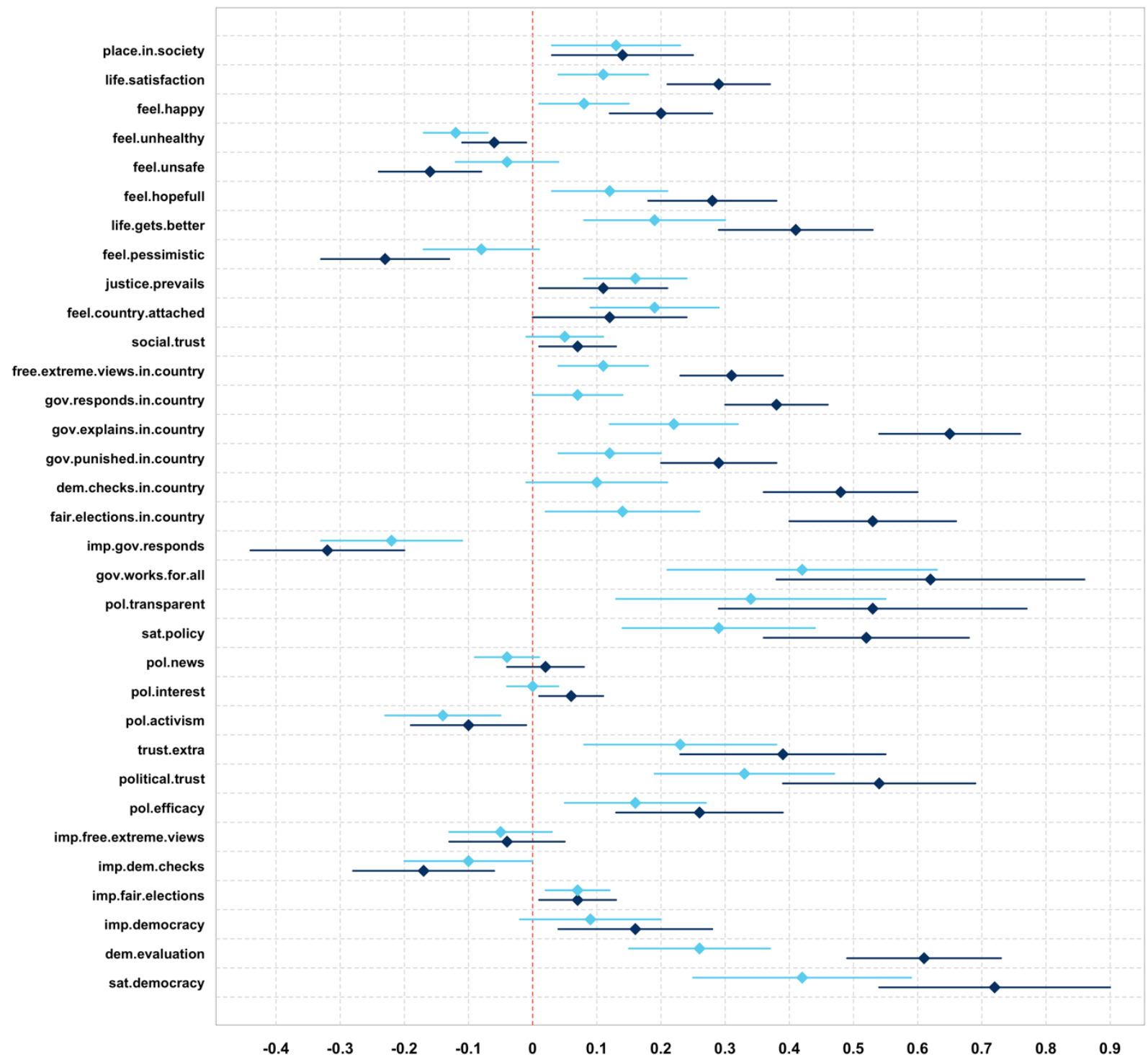

Figure 3. Coefficients and 95\% confidence intervals for the effects of voting for a winning party among partisans in old and new (post-1989) democracies 
While experience with democracy appears to be an important moderator of the effects of winning at democratic elections, there is much less evidence in support for the hypothesis that the disproportionality of the electoral system plays a similar role. Looking at columns 13 to 15 of Figure 2, we only find significant interaction effects with respect to the importance of fair elections (among citizens and voters, but not among partisans) and political interest. The positive effect of winning on the importance of fair elections and the negative effect on political interest are even stronger in more disproportional systems.

We also tested the possibly moderating role of gender. The sign and significance of the interaction effects are reported in the last three columns of Figure 2. There is evidence for systematic differences across men and women for several outcomes variables of interest. The positive effects of winning on satisfaction with and evaluation of democracy, political efficacy, and satisfaction with policy, as well as the negative effect on the importance of government responsiveness to citizens, are even stronger for males. There are some significant differences with respect to social trust, optimism for society (life gets better) and feeling of happiness and life satisfaction as well. Yet, for many political and social attitudes there is no evidence for an interaction of winner status with gender, and there does not seem to be an obvious pattern that can account for which outcome there is an interaction effect and for which outcome there is none.

\section{Part IV. In and out of government}

All analyses reported above rely on comparisons between voters for winning parties (those that are in government) and losing parties at a single point of time. But it could be that citizens with different attitudes sort themselves differentially into parties that would win and lose elections. Such sorting could (partly) explain the winner-loser gaps that we observe. The individual-level covariates we include in the models control to some extent for relevant prior differences in attitudes and life outlook between winners and losers, but some self-selection effect might remain.

To address this potential issue, this part of the analysis focuses on the changes in the attitudes of citizens whose favoured party goes in and out of government between the two observation points - 2012 and 2018. To set up the data for the analysis, we first identified the 2012 respondents who had voted for parties that were in power in 2012 (group A) and that would be in power in 2018 (group B). Then we identified the 2018 respondents who had voted for parties that had been in power in 2012 (group C) and that were in power in 2018 (group D). We expect that average satisfaction with democracy, trust, happiness, etc., will be higher in group D compared to group B (because group D 
is in power in 2018, while B is in opposition in 2012) and will be lower in group C compared to group A (because group C is in opposition in 2018, while it is in power in 2012).

Table 3. Classification of citizens 'defeated' and 'gainers'

\begin{tabular}{|l|c|c|c|}
\hline & $\begin{array}{l}\text { Voted for parties in } \\
\text { government in } 2012\end{array}$ & $\begin{array}{l}\text { Voted for parties in } \\
\text { government in 2018 }\end{array}$ & $\begin{array}{l}\text { Voted for parties not in } \\
\text { government 2012 \& 2018 }\end{array}$ \\
\hline Respondents in 2012 survey & A: 2012 winners & B: 2018 winners & Others \\
\hline Respondents in 2018 survey & C: 2012 winners & D: 2018 winners & Others \\
\hline
\end{tabular}

To examine these hypotheses we create a categorical variable that splits the population in three subsets: 2018 winners, or 'gainers' (groups B and D), 2012 winners, or 'defeated' (groups A and C), and the rest (baseline category, composed of citizens who either didn't vote or voted for a party that was not in power in any of the two years), as explained in Table 3. Note that the labels gainers and defeated in this context are terms relative to the changes between 2018 and 2012: the gainers are actually on the losing side in 2012 and the defeated are in government in 2012. We then set up regression models in which we interact this categorical variable with an indicator for the year. A significant positive interaction between gainers and year would indicate that voters who got in power in 2018 increase their satisfaction with government, trust, etc. more than the baseline group (or decreased it to a smaller extent). A significant negative interaction between defeated and year would indicate that voters for parties who lost power between 2012 and 2018 decreased satisfaction with government, trust, etc. more than the baseline group (or increased it to a smaller extent). The main coefficients for gainers and defeated indicate differences compared to the baseline category as of 2012. The main coefficient for year indicates the change between 2018 and 2012 for the baseline category.

There are twelve outcome variables of interest for which information is available in both the 2012 and 2018 waves of the ESS. In principle, the analysis can rely on information from 20 countries for which data is available both in 2012 and 2018 (data on three more countries for 2018 is to be released in the near future). However, for some of these countries, some of the parties remain in government in both periods (Slovakia, Estonia, Belgium, Hungary, UK, Bulgaria, Ireland, Finland, Germany). In these cases some coalition partners might still have been dropped or added. In four countries, some of the governing parties in 2018 are not featured in the 2012 survey (Czechia, Italy, France, Slovenia). And in a couple of cases the data collection period for the survey coincides with government changes (the Netherlands, Bulgaria). This leaves Sweden, Portugal, Spain, Poland, Norway, and Cyprus as cases of clear government changes between 2018 and 2012 with information 
for all parties available. While in the analyses reported below we include data from all 20 countries, we would expect the findings to be most precisely estimated for the latest group of countries with complete data and government changes.

The regression models we report below feature the usual set of demographic covariates - age, gender, education, occupation, new/old democracy indicator, and random intercepts and slopes (for the effect of defeated/gainer status) at the country level. What is new is the addition of the year as a fixed effect and its interaction with the status variable.

Table 4. Coefficients and standard errors (multiplied by 2) of the effects of gainer/defeated status, year and their interaction for 12 outcome variables of interest, based on multilevel regression models

\begin{tabular}{|c|c|c|c|c|c|c|c|c|c|c|}
\hline Variable & $\begin{array}{l}\text { Coef. } \\
\text { Deftd }\end{array}$ & $\begin{array}{l}\text { 2SE. } \\
\text { Deftd }\end{array}$ & $\begin{array}{l}\text { Coef. } \\
\text { Gainer }\end{array}$ & $\begin{array}{l}\text { 2SE. } \\
\text { Gainer }\end{array}$ & $\begin{array}{l}\text { Coef. } \\
\text { Year }\end{array}$ & $\begin{array}{l}\text { 2SE. } \\
\text { Year }\end{array}$ & $\begin{array}{l}\text { Coef. } \\
\text { Year.Deftd }\end{array}$ & $\begin{array}{r}\text { 2SE. } \\
\text { Year.Deftd }\end{array}$ & $\begin{array}{r}\text { Coef. } \\
\text { Year.Gainer }\end{array}$ & $\begin{array}{r}\text { 2SE. } \\
\text { Year.Gain }\end{array}$ \\
\hline sat.democracy & 0.25 & 0.08 & 0.17 & 0.08 & 0.01 & 0.02 & -0.18 & 0.04 & 0.13 & 0.03 \\
\hline political.trust & 0.27 & 0.06 & 0.21 & 0.06 & 0.20 & 0.02 & -0.15 & 0.04 & 0.10 & 0.03 \\
\hline trust.extra & 0.19 & 0.06 & 0.15 & 0.05 & 0.21 & 0.02 & -0.09 & 0.04 & 0.04 & 0.03 \\
\hline pol.activism & 0.16 & 0.07 & 0.10 & 0.05 & 0.08 & 0.02 & -0.01 & 0.04 & -0.02 & 0.03 \\
\hline pol.interest & 0.34 & 0.07 & 0.33 & 0.06 & 0.02 & 0.02 & -0.07 & 0.04 & -0.07 & 0.03 \\
\hline pol.news & 0.07 & 0.03 & 0.07 & 0.04 & 0.19 & 0.02 & 0.04 & 0.04 & 0.05 & 0.03 \\
\hline sat.policy & 0.19 & 0.07 & 0.11 & 0.06 & 0.27 & 0.02 & -0.15 & 0.03 & 0.09 & 0.03 \\
\hline social.trust & 0.12 & 0.04 & 0.08 & 0.04 & 0.04 & 0.02 & -0.02 & 0.04 & 0.05 & 0.03 \\
\hline feel.unsafe & -0.08 & 0.05 & -0.06 & 0.03 & -0.08 & 0.02 & -0.01 & 0.04 & -0.02 & 0.03 \\
\hline feel.unhealthy & -0.06 & 0.06 & -0.08 & 0.05 & -0.00 & 0.02 & -0.04 & 0.04 & -0.03 & 0.03 \\
\hline feel.happy & 0.15 & 0.05 & 0.14 & 0.04 & 0.12 & 0.02 & -0.05 & 0.04 & -0.01 & 0.03 \\
\hline life.satisfaction & 0.13 & 0.06 & 0.13 & 0.05 & 0.10 & 0.02 & -0.02 & 0.04 & -0.01 & 0.03 \\
\hline
\end{tabular}

Table 4 shows the estimated coefficients and standard errors (multiplied by two for easier comparison to the coefficients) for the effects of status, year and their interaction. The most relevant columns are the last four, which show how attitudes have changed between 2018 and 2012 for voters of parties who got into government in 2018 (gainers) and for voters of parties who were in government in 2012 but not anymore in 2018 (defeated). The significant interaction effects are in bold. 
Coefficients and $95 \%$ confidence intervals for the effects of election status on change in attit for citizens who gained and who were defeated between 2018 and 2012

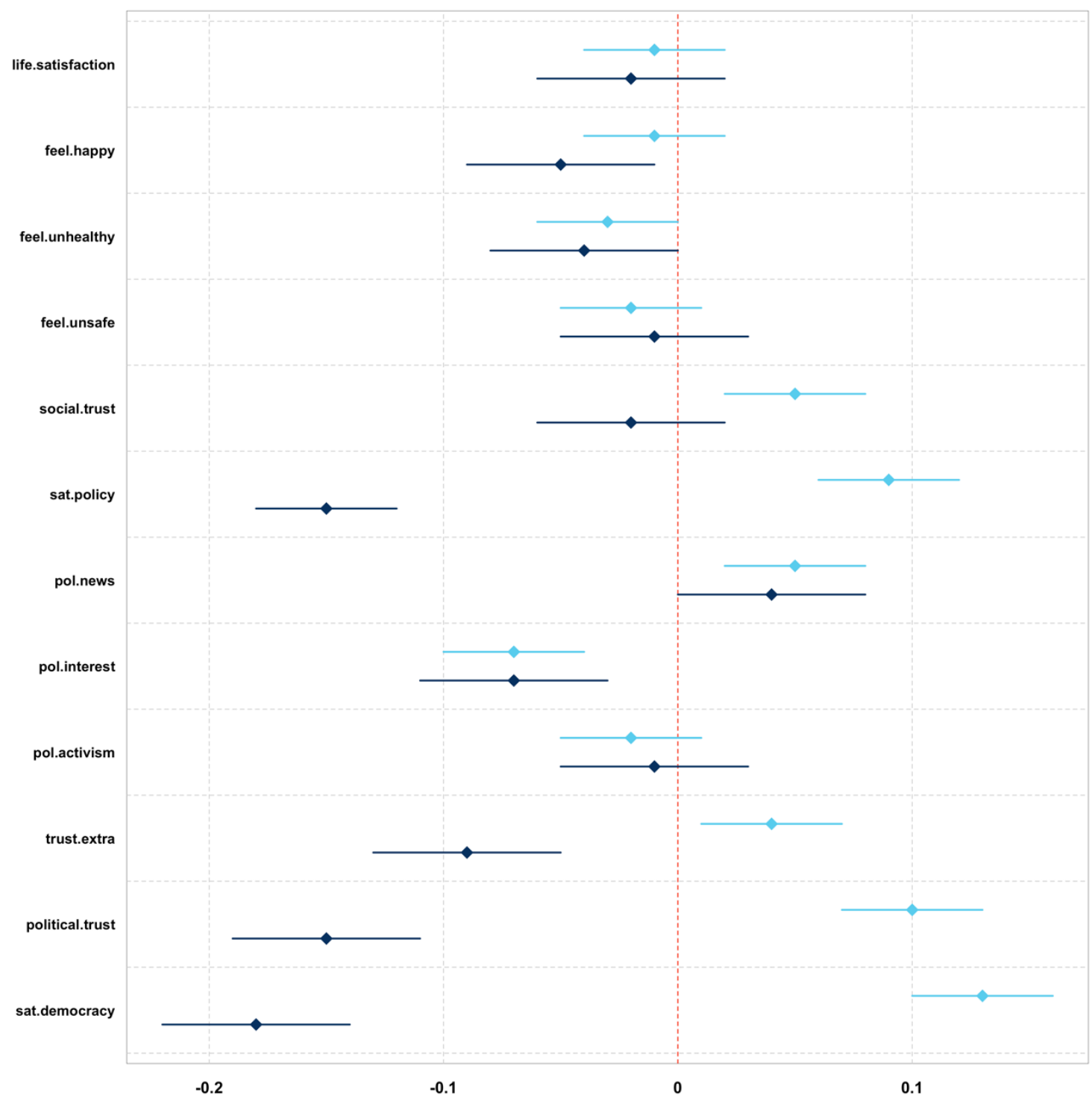

Figure 4. Coefficients and 95\% confidence intervals for the effects of election status (gainer or defeated between 2018 and 2012) among citizens compared to the changes in the baseline category of citizens (who were not represented in government neither in 2012 nor in 2018).

The first columns of Table 4 indicate that while voters of parties in government in 2012 (first two columns) have higher values on the relevant attitudes than the baseline, the voters of the opposition parties that would be in government in 2018 (gainers) also have higher values, although in most cases not quite as high as the voters for the incumbents in 2012. This suggest that the effects reported in the previous sections are driven partly by low values on the outcome variables of citizens who voted 
for parties that did not make it into government in 2012 nor in 2018. Looking at the interaction effects, for some of the outcome variables we see the expected pattern - significant and differently-signed coefficients of the interaction of status with time, but not for all.

For example, examining the first row of the table that focuses on satisfaction with democracy we can see that voters for parties that were in government in 2012 significantly decreased their satisfaction in 2018 compared to 2012, while the voters for parties that were not in government in 2012 but gained power in 2018 significantly increased their satisfaction, relative to the changes experienced by the baseline group of voters who were not in power at any of the two time periods. The same pattern holds also for political trust, trust in the legal system and the police (trust.extra), and policy satisfaction. Social trust increases for gainers, but does not decrease for defeated voters. Feelings of happiness decrease for defeated, but do not increase for gainers (more than for the baseline group). The results with regard to political interest and the consumption of political news are not consistent with our hypotheses (and the results from the previous analyses), because both gainers and defeated show significant changes. Finally, for some variables - political activism, feeling unsafe, and life satisfaction, there are no significant changes between 2018 and 2012 that work differentially depending on the election winner status. Figure 4 shows graphically the gap between gainers and defeated for all citizens. The results are largely the same when we consider voters and partisans only.

The fact that we do not see the expected interactions for all variables in this part of the analysis does not need to imply that the winners-losers gap does not exist for these variables. As mentioned above, not all countries in the sample experience complete change in government between 2018 and 2012, which would dilute the effect of gaining or losing power. More importantly, the baseline group to which we compare 'gainers' and 'defeated' voters consists of respondents who did not vote or voted for parties that did not gain office in any of the two elections. So finding the winners-losers gap in the first set of cross-sectional analyses but not in the analyses presented in this section might simply mean that, for some outcomes of interest, the gap is much greater between occasional winners and persistent electoral losers than between occasional winners and occasional losers.

\section{Conclusion}

This article presented a comprehensive study of the effects of winning and losing democratic elections

on a wide set of political and social attitudes, life outlook and subjective well-being. In addition to the well-documented effects on satisfaction with democracy, we find comparable effects on other attitudes related to democracy and features of the democratic process, political trust, efficacy, activism 
and interest, expectations about government responsiveness, perceptions of how government and politics work in the country of the respondent, social trust, country attachment, perceptions of justice in the world, outlook on life, self-perceived safety, health, happiness, life satisfaction and place in society.

Most of these effects were in the hypothesized directions, including, for example, positive effects on perceived political efficacy and the importance of fair elections, but negative effects of winning on support for democratic checks and balances and the freedom to express extreme views. The effects were particularly strong when it comes to perceptions about how government and politics work in the country of the respondent. One outcome variable for which we found strong effects but in the opposite of the predicted direction was the perceived importance of government responsiveness: election winners turned out to be significantly less likely to find responsiveness important, possibly because they prefer the government to stick to its electoral pledges, which they have voted for, rather than follow public opinion.

For the political attitudes where no straightforward hypotheses could be formed, we find negative effects of winning on political interest, no consistent effects on the consumption of political news, and heterogenous effects on political activism: positive in the entire population, but negative among the subset of voters and partisans. So winning might energize non-voters and people without strong party attachments, but demobilize the core of party supporters.

Outside the domain of politics, we uncovered a significant gap between winners and losers with respect to many variables related to people's outlook on society, the future, and themselves. Even if the gap between winners and loser is not strictly speaking caused by winning or losing at the latest election, but reflects prior and more fundamental personal differences, it remains substantially important. If being on the losing side of democratic politics is systematically related to being less happy, optimistic, satisfied in life, and even healthy, then it is not surprising for people to turn to antisystemic parties or become politically disengaged altogether (Nowakowski, 2020).

Interestingly, we find that, similarly to political attitudes, the winners-losers gap in life outlook and well-being is mediated by satisfaction with the current government. This makes it less likely that the effects are produced by the mere fact of wining at a (political) competition and more likely that good political representation also plays a role in whether you consider yourself a political loser, with the associated effects on subjective well-being and perceived place in society.

It is also noteworthy that most effects we see are weaker in old, established democracies. At the same time, we do not see much evidence that these effects decline in size over the period we 
examine, and even the 'new' democracies in our sample have transitioned from authoritarian rule more than 20 years before the data was collected. So even if experience with democracy decreases the winners-losers gap, the effect might take a very long time to make a difference. With a couple of small exceptions, we do not find evidence that the disproportionality of the electoral system - one important institutional feature of democratic politics - has an impact on the winners-losers gap.

There is evidence that the size of the gap differs for men and women, at least for some of the outcome variables of interest - which would speak in favor of physiological mechanisms being responsible for the gap - but more research is need to establish why some outcomes are affected differently based on the gender of the respondents, but others not.

What we find ample evidence about is that for almost all outcomes the gap between winners and losers is greater when we consider the subset of people with strong party attachments (partisans). Apparently, the more invested you are in the political game, the harder it is when you lose, and the consequences for everything from satisfaction with democracy to satisfaction with your own life are greater. We find smaller differences in the results when we conduct the analysis for the subset of voters only, which speaks against the idea that the gap with election winners is driven by non-voters.

Further research is needed to establish whether the effects we find stem from winners getting more positive, losers getting more negative, or both; whether the effects are cumulative over time; and how long they last. It would also be valuable to test the hypotheses with other kinds of data and research designs to probe both the generalizability of the findings to other geographical regions and to see if the results would replicate with panel data, which would speak to the causal nature of the winning and losing effects. At the very least, our findings suggest that political scientists should cast a much wider net when they consider the consequences of winning and losing elections.

To conclude, the consent of losers is necessary for the well-being of democracy, but it sucks to be an election loser, and apparently this can affect anything from your assessment of the importance of democracy to how happy, healthy and optimistic you feel. This raises important concerns about the sustainability of democratic societies, in which some citizens consistently find themselves on the losing side of politics. But one optimistic implication of our research is that being satisfied with the current government can neutralize to a large extent the effects of losing at the election. How governments can satisfy people who did not vote for them remains a question for future research. 


\section{References}

Anderson, C. J., Blais, A., \& Bowler, S. (2005). Losers' consent: elections and democratic legitimacy. Oxford University Press.

Anderson, C. J., \& Guillory, C. A. (1997). Political Institutions and Satisfaction with Democracy: A Cross-National Analysis of Consensus and Majoritarian Systems. The American Political Science Review, 91(1), 66-81.

Anderson, C. J., \& Tverdova, Y. V. (2001). Winners, Losers, and Attitudes about Government in Contemporary Democracies. International Political Science Review, 22(4), 321-338.

Bates, D., Mächler, M., Bolker, B., \& Walker, S. (2015). Fitting Linear Mixed-Effects Models Using lme4. Journal of Statistical Software; Vol 1, Issue 1 (2015) . https://doi.org/10.18637/jss.v067.i01

Berliner, D. (2020). Partisan Context and Procedural Values: Attitudes towards Presidential Secrecy before and after the 2016 US Election. British Journal of Political Science, 1-9. https://doi.org/10.1017/S0007123420000265

Blais, A., \& Gélineau, F. (2007). Winning, losing and satisfaction with democracy. Political Studies, 55(2), 425-441. https://doi.org/10.1111/j.1467-9248.2007.00659.x

Blais, A., Morin-Chassé, A., \& Singh, S. (2017). Election outcomes, legislative representation, and satisfaction with democracy. Party Politics, 23(2), 85-95. https://doi.org/10.1177/1354068815583200

Bol, D., Blais, A., Gillard, X., Nunez Lopez, L., \& Pilet, J. B. (2018). Voting and satisfaction with democracy in flexible-list PR. Electoral Studies, 56(June), 23-34. https://doi.org/10.1016/j.electstud.2018.09.007

Boyer, P., Firat, R., \& van Leeuwen, F. (2015). Safety, Threat, and Stress in Intergroup Relations: A Coalitional Index Model. Perspectives on Psychological Science, 10(4), 434-450. https://doi.org/10.1177/1745691615583133

Brummel, L. (2020). 'You Can't Always Get What You Want': The effects of winning and losing in a referendum on citizens' referendum support. Electoral Studies, 65(March), 102155. https://doi.org/10.1016/j.electstud.2020.102155

Buser, T. (2016). The impact of losing in a competition on the willingness to seek further challenges. Management Science, 62(12), 3439-3449.

Carré, J. M., Campbell, J. A., Lozoya, E., Goetz, S. M. M., \& Welker, K. M. (2013). Changes in testosterone mediate the effect of winning on subsequent aggressive behaviour. Psychoneuroendocrinology, $\quad 38(10), \quad 2034-2041$. https://doi.org/https://doi.org/10.1016/j.psyneuen.2013.03.008

Cimentada, J. (2019). Download data from the European Social Survey on the Fly R package version 1.0. 3.

Curini, L., Jou, W., \& Memoli, V. (2012). Satisfaction with democracy and the winner/loser debate: The role of policy preferences and past experience. British Journal of Political Science, 42(2), 241261. https://doi.org/10.1017/S0007123411000275

Dahlberg, S., \& Linde, J. (2017). The dynamics of the winner-loser gap in satisfaction with democracy: Evidence from a Swedish citizen panel. International Political Science Review, 38(5), 625-641. https://doi.org/10.1177/0192512116649279

Davis, N. T. (2014). Responsiveness and the rules of the game: How disproportionality structures the effects of winning and losing on external efficacy. Electoral Studies, 36, 129-136. https://doi.org/10.1016/j.electstud.2014.09.003

Davis, N. T., \& Hitt, M. P. (2016). Winning, Losing, and the Dynamics of External Political Efficacy. International Journal of Public Opinion Research, 29(4), edw013. https://doi.org/10.1093/ijpor/edw013

Delgado, I. (2016). How governing experience conditions winner-loser effects. An empirical analysis 
of the satisfaction with democracy in Spain after 2011 elections. Electoral Studies, 44, 76-84. https://doi.org/https://doi.org/10.1016/j.electstud.2016.07.007

Esaiasson, P. (2011). Electoral losers revisited - How citizens react to defeat at the ballot box. Electoral Studies, 30(1), 102-113. https://doi.org/10.1016/j.electstud.2010.09.009

European Social Survey. (2012). ESS Round 6 Source Questionnaire. London: Centre for Comparative Social Surveys, City University London, accessed at https://www.europeansocialsurvey.org/data/round-index.html, 10 November 2020.

European Social Survey. (2018). ESS Round 9 Source Questionnaire. London: Centre for Comparative Social Surveys, City University London, accessed at https://www.europeansocialsurvey.org/data/round-index.html, 10 November 2020.

Farrer, B., \& Zingher, J. N. (2019). A global analysis of how losing an election affects voter satisfaction with democracy. International Political Science Review, 40(4), 518-534. https://doi.org/10.1177/0192512118779213

Ferland, B. (2020). Policy congruence and its impact on satisfaction with democracy. Electoral Studies, November 2019, 102204. https://doi.org/10.1016/j.electstud.2020.102204

Fuchs, D., Guidorossi, G., \& Svensson, P. (1995). Support for the democratic system. In H. Klingemann \& D. Fuchs (Eds.), Citizens and the state. Oxford University Press.

Gallagher, M. (1991). Proportionality, disproportionality and electoral systems. Electoral Studies, 10(1), 33-51. https://doi.org/https://doi.org/10.1016/0261-3794(91)90004-C

Gärtner, L., Gavras, K., \& Schoen, H. (2020). What tips the scales? Disentangling the mechanisms underlying post-electoral gains and losses in democratic support. Electoral Studies, 67(February). https://doi.org/10.1016/j.electstud.2020.102210

Graham, M. H., \& Svolik, M. W. (2020). Democracy in America? Partisanship, Polarization, and the Robustness of Support for Democracy in the United States. American Political Science Review, 114(2), 392-409. https://doi.org/10.1017/S0003055420000052

Gunnar, M., \& Quevedo, K. (2006). The Neurobiology of Stress and Development. Annual Review of Psychology, 58(1), 145-173. https://doi.org/10.1146/annurev.psych.58.110405.085605

Han, S. M., \& Chang, E. C. C. (2016). Economic inequality, winner-loser gap, and satisfaction with democracy. Electoral Studies, 44, 85-97. https://doi.org/10.1016/j.electstud.2016.08.006

Hansen, S. W., Klemmensen, R., \& Serritzlew, S. (2019). Losers lose more than winners win: Asymmetrical effects of winning and losing in elections. European Journal of Political Research, 58(4), 1172-1190. https://doi.org/10.1111/1475-6765.12329

Hooghe, M., \& Stiers, D. (2016). Elections as a democratic linkage mechanism: How elections boost political trust in a proportional system. Electoral Studies, 44, 46-55. https://doi.org/10.1016/j.electstud.2016.08.002

Howell, P., \& Justwan, F. (2013). Nail-biters and no-contests: The effect of electoral margins on satisfaction with democracy in winners and losers. Electoral Studies, 32(2), 334-343. https://doi.org/https://doi.org/10.1016/j.electstud.2013.02.004

Imai, K., Keele, L., \& Tingley, D. (2010). A general approach to causal mediation analysis. Psychological Methods, 15(4), 309.

Knight, E. L., \& Mehta, P. H. (2014). Hormones and Hierarchies BT - The Psychology of Social Status (J. T. Cheng, J. L. Tracy, \& C. Anderson (eds.); pp. 269-301). Springer New York. https://doi.org/10.1007/978-1-4939-0867-7_13

Linde, J., \& Ekman, J. (2003). Satisfaction with democracy: A note on a frequently used indicator in comparative politics. European Journal of Political Research, 42(3), 391-408. https://doi.org/10.1111/1475-6765.00089

Longman, D. P., Surbey, M. K., Stock, J. T., \& Wells, J. C. K. (2018). Tandem Androgenic and Psychological Shifts in Male Reproductive Effort Following a Manipulated "Win" or "Loss" in 
a Sporting Competition. Human Nature (Hawthorne, N.Y.), 29(3), 283-310. https://doi.org/10.1007/s12110-018-9323-5

Loveless, M. (2020). When You Win, Nothing Hurts: The Durability of Electoral Salience on Individuals' Satisfaction with Democracy. Political Studies. https://doi.org/10.1177/0032321720910356

Lüdecke, D. (2018). sjPlot: Data visualization for statistics in social science. R Package Version, 2(1).

McAuley, E., Russell, D., \& Gross, J. B. (1983). Affective Consequences of Winning and Losing: An Attributional Analysis. Journal of Sport Psychology, 5(3), 278-287. https://doi.org/10.1123/jsp.5.3.278 10.1123/jsp.5.3.278

McCaul, K. D., Gladue, B. A., \& Joppa, M. (1992). Winning, losing, mood, and testosterone. Hormones and Behavior, 26(4), 486-504. https://doi.org/https://doi.org/10.1016/0018-506X(92)90016-O

Mesterton-Gibbons, M., Dai, Y., \& Goubault, M. (2016). Modeling the evolution of winner and loser effects: A survey and prospectus. Mathematical Biosciences, 274, 33-44. https://doi.org/https://doi.org/10.1016/j.mbs.2016.02.002

Moehler, D. C. (2009). Critical citizens and submissive subjects: Election losers and winners in Africa. British Journal of Political Science, 39(2), 345-366.

Monsiváis-Carrillo, A. (2020). Permissive Winners? The Quality of Democracy and the Winner-Loser Gap in the Perception of Freedoms. Political Studies, 0032321720952230. https://doi.org/10.1177/0032321720952230

Nowakowski, A. (2020). Do unhappy citizens vote for populism? European Journal of Political Economy, 101985. https://doi.org/https://doi.org/10.1016/j.ejpoleco.2020.101985

Oliveira, T., Gouveia, M. J., \& Oliveira, R. F. (2009). Testosterone responsiveness to winning and losing experiences in female soccer players. Psychoneuroendocrinology, 34(7), 1056-1064. https://doi.org/https://doi.org/10.1016/j.psyneuen.2009.02.006

Petersen, M. B., Tybur, J. M., \& Stewart, P. A. (2020). Disgust and political attitudes: Guest Editors' Introduction to the Special Issue. Politics and the Life Sciences, 39(2), 129-134. https://doi.org/DOI: 10.1017/pls.2020.23

Plescia, C. (2019). On the Subjectivity of the Experience of Victory: Who Are the Election Winners? Political Psychology, 40(4), 797-814. https://doi.org/10.1111/pops.12562

Sapolsky, R. M. (2007). Stress, stress-related disease, and emotional regulation. In J. J. Gross (Ed.), Handbook of emotion regulation (pp. 606-615). New York, NY: Guilford Press.

Singer, M. (2018). Delegating Away Democracy: How Good Representation and Policy Successes Can Undermine Democratic Legitimacy. Comparative Political Studies, 51(13), 1754-1788. https://doi.org/10.1177/0010414018784054

Singh, S. (2014). Not all election winners are equal: Satisfaction with democracy and the nature of the vote. European Journal of Political Research, 53(2), 308-327. https://doi.org/10.1111/14756765.12028

Singh, S., Karakoç, E., \& Blais, A. (2012). Differentiating winners: How elections affect satisfaction with democracy. Electoral Studies, 31(1), 201-211. https://doi.org/10.1016/j.electstud.2011.11.001

Singh, S., \& Thornton, J. R. (2019). Elections Activate Partisanship across Countries. American Political Science Review, 113(1), 248-253. https://doi.org/10.1017/S0003055418000722

Stanton, S. J., Beehner, J. C., Saini, E. K., Kuhn, C. M., \& LaBar, K. S. (2009). Dominance, Politics, and Physiology: Voters' Testosterone Changes on the Night of the 2008 United States Presidential Election. PLOS ONE, 4(10), e7543. https://doi.org/10.1371/journal.pone.0007543

Stecker, C., \& Tausendpfund, M. (2016). Multidimensional government-citizen congruence and satisfaction with democracy. European Journal of Political Research, 55(3), 492-511. https://doi.org/10.1111/1475-6765.12147 
Stiers, D., Daoust, J. F., \& Blais, A. (2018). What makes people believe that their party won the election? Electoral Studies, 55(January), 21-29. https://doi.org/10.1016/j.electstud.2018.07.002

Tingley, D., Yamamoto, T., Hirose, K., Keele, L., \& Imai, K. (2014). Mediation: R package for causal mediation analysis. Journal of Statistical Software.

van der Meer, T. W. G., \& Steenvoorden, E. H. (2018). Going back to the well: A panel study into the election boost of political support among electoral winners and losers. Electoral Studies, 55(June), 40-53. https://doi.org/10.1016/j.electstud.2018.06.007

VanDusky-Allen, J. (2017). Winners, losers, and protest behavior in parliamentary systems. The Social Science Journal, 54(1), 30-38. https://doi.org/https://doi.org/10.1016/j.soscij.2016.12.003

Vongas, J. G., \& Al Hajj, R. (2015). Competing sexes, power, and testosterone: How winning and losing affect people's empathic responses and what this means for organisations. Applied Psychology, 64(2), 308-337.

Williams, N. S., Snipes, A., \& Singh, S. (2020). Gender differences in the impact of electoral victory on satisfaction with democracy. Electoral Studies, 102205. https://doi.org/https://doi.org/10.1016/j.electstud.2020.102205

Wuttke, A., Gavras, K., \& Schoen, H. (2020). Have Europeans Grown Tired of Democracy? New Evidence from Eighteen Consolidated Democracies, 1981-2018. British Journal of Political Science, 1-13. https://doi.org/DOI: 10.1017/S0007123420000149

Yan, B. W., Hsia, R. Y., Yeung, V., \& Sloan, F. A. (2020). Changes in Mental Health Following the 2016 Presidential Election. Journal of General Internal Medicine. https://doi.org/10.1007/s11606020-06328-6 


\section{Supplementary material}

\section{Full results from the multilevel models to be presented with a Shiny application}

The full results of the multilevel models are available via an interactive app, available at: https://dimiter.shinyapps.io/election winners effects/. The app allows the user to specify the outcome variable of interest, choose some the covariates to include or not (including the mediator satisfaction with government), select interaction effects, and subset to the subpopulations of voters and partisans, as defined in this article.

\section{Outcome variables: question wording and measurement scales}

Table A1. Question labels, formulations and answer scales

\begin{tabular}{|c|c|c|}
\hline Label & Question wording & Answer scale \\
\hline sat.democracy & $\begin{array}{l}\text { And on the whole, how satisfied are you with the way democracy works in } \\
\text { [country]? }\end{array}$ & 0 to 10 \\
\hline dem.evaluation & How democratic [country] is overall? & 0 to 10 \\
\hline imp.democracy & How important is it for you to live in a country that is governed democratically? & 0 to 10 \\
\hline imp.fair.elections & $\begin{array}{l}\text { Using this card, please tell me how important you think it is for democracy in } \\
\text { general......that national elections are free and fair? }\end{array}$ & 0 to 10 \\
\hline imp.dem.checks & $\begin{array}{l}\text { Using this card, please tell me how important you think it is for democracy in } \\
\text { general... } \\
\text {...that opposition parties are free to criticise the government? } \\
\text {...that the media are free to criticise the government? } \\
\text {...that the courts are able to stop the government acting beyond its authority? }\end{array}$ & $\begin{array}{l}0 \text { to } 10 \\
0 \text { to } 10 \\
0 \text { to } 10 \\
\text { Sum of the three! }\end{array}$ \\
\hline imp.free.extreme.views & $\begin{array}{l}\text { There are differing opinions on whether or not everyone should be free to } \\
\text { express their political views openly in a democracy, even if they are extreme. } \\
\text { Which one of the statements on this card describes what you think is best for } \\
\text { democracy in general? }\end{array}$ & $\begin{array}{l}1 \text { Free to express } \\
\text { extreme political } \\
\text { views, even } \\
\text { extreme } \\
2 \text { Prevented from } \\
\text { expressing extreme } \\
\text { political views } \\
5 \text { It depends on } \\
\text { the circumstances } \\
\text { Recoded into } 1 \\
[1] / 0 \text { [2 and } 5]\end{array}$ \\
\hline pol.efficacy & $\begin{array}{l}\text { How much would you say the political system in [country] allows people like } \\
\text { you to have a say in what the government does? } \\
\text { How able do you think you are to take an active role in a group involved with } \\
\text { political issues? } \\
\text { And how much would you say that the political system in [country] allows } \\
\text { people like you to have an influence on politics? } \\
\text { And how confident are you in your own ability to participate in politics? } \\
\text { Political system in country ensures everyone fair chance to participate in } \\
\text { politics. }\end{array}$ & $\begin{array}{l}1 \text { Not at all } \\
\text { to } \\
5 \text { A great } \\
\text { deal/Completely } \\
\text { able/confident } \\
\text { Sum of the five! }\end{array}$ \\
\hline political.trust & $\begin{array}{l}\text { Using this card, please tell me on a score of } 0-10 \text { how much you personally } \\
\text { trust each of the institutions I read out Firstly... } \\
\text {... [country]'s parliament? } \\
\text {-..politicians? } \\
\text {...political parties? }\end{array}$ & $\begin{array}{l}0 \text { to } 10 \\
0 \text { to } 10 \\
0 \text { to } 10 \\
\text { Sum of the three! }\end{array}$ \\
\hline trust.extra & $\begin{array}{l}\text { Using this card, please tell me on a score of } 0-10 \text { how much you personally } \\
\text { trust each of the institutions I read out Firstly... } \\
\text {...the legal system? } \\
\text {...the police? }\end{array}$ & $\begin{array}{l}0 \text { to } 10 \\
0 \text { to } 10 \\
\text { Sum of the two! }\end{array}$ \\
\hline pol.activism & $\begin{array}{l}\text { There are different ways of trying to improve things in [country] or help prevent } \\
\text { things from going wrong. During the last } 12 \text { months, have you done any of the } \\
\text { following? Have you... ...contacted a politician, government or local } \\
\text { government official? ...worked in a political party or action group? ...worn or }\end{array}$ & $\begin{array}{l}1 \text { yes, } 2 \text { no for each } \\
\text { Recoded into } 1 / 0 \\
\text { and sum of the six! }\end{array}$ \\
\hline
\end{tabular}




\begin{tabular}{|c|c|c|}
\hline & $\begin{array}{l}\text { displayed a campaign badge/sticker? ...signed a petition? ...taken part in a lawful } \\
\text { public demonstration? ...boycotted certain products? }\end{array}$ & \\
\hline pol.interest & How interested would you say you are in politics - are you... & $\begin{array}{l}1 \text { [very interested] } \\
\text { to } 4 \text { [not at all } \\
\text { interested] } \\
\text { Inverted! }\end{array}$ \\
\hline pol.news & $\begin{array}{l}\text { And again on an average weekday, how much of your time watching television } \\
\text { is spent watching news or programmes about politics and current affairs? [2012] } \\
\text { On a typical day, about how much time do you spend watching, reading or } \\
\text { listening to news about politics and current affairs? [2018] }\end{array}$ & $\begin{array}{l}0-\text { No time at all } \\
\text { to } 7-\text { More than } 3 \\
\text { hours [2012] } \\
\text { In minutes. [2018] } \\
\text { Recorded to match } \\
2012 \text { scale! }\end{array}$ \\
\hline sat.policy & $\begin{array}{l}\text { On the whole how satisfied are you with the present state of the economy in } \\
\text { [country]? } \\
\text { Now, using this card, please say what you think overall about the state of } \\
\text { education in [country] nowadays? } \\
\text {... about the state of health services in [country] nowadays? }\end{array}$ & $\begin{array}{l}0 \text { to } 10 \\
0 \text { to } 10 \\
0 \text { to } 10 \\
\text { Sum of the three! }\end{array}$ \\
\hline pol.transparent & $\begin{array}{l}\text { How much would you say that decisions in [country] politics are transparent, } \\
\text { meaning that everyone can see how they were made? }\end{array}$ & $\begin{array}{l}1 \text { Not at all } \\
\text { to } \\
5 \text { A great deal }\end{array}$ \\
\hline gov.works.for.all & $\begin{array}{l}\text { How much would you say that the government in [country] takes into account } \\
\text { the interests of all citizens? }\end{array}$ & $\begin{array}{l}1 \text { Not at all } \\
\text { to } \\
5 \text { A great deal }\end{array}$ \\
\hline imp.gov.responds & $\begin{array}{l}\text { Sometimes the government disagrees with what most people think is best for } \\
\text { the country. Which one of the statements on this card describes what you think } \\
\text { is best for democracy in general? }\end{array}$ & $\begin{array}{l}1 \text { Gov. should } \\
\text { change its policies } \\
2 \text { Gov. should stick } \\
\text { to its policies } \\
5 \text { It depends on the } \\
\text { circumstances } \\
\text { Recoded into } 1 \\
{[1] / 0[2 \text { and } 5]}\end{array}$ \\
\hline fair.elections.in.country & $\begin{array}{l}\text { Using this card, please tell me to what extent you think each of the following } \\
\text { statements applies in [country]. } 0 \text { means you think the statement does not apply } \\
\text { at all and } 10 \text { means you think it applies completely. National elections in } \\
\text { [country] are free and fair. }\end{array}$ & 0 tot 10 \\
\hline dem.checks.in.country & $\begin{array}{l}\text { Opposition parties in [country] are free to criticise the government. } \\
\text { The media in [country] are free to criticise the government. }\end{array}$ & $\begin{array}{l}0 \text { to } 10 \\
0 \text { to } 10 \\
\text { Sum of the two! }\end{array}$ \\
\hline gov.punished.in.country & $\begin{array}{l}\text { Governing parties in [country] are punished in elections when they have done } \\
\text { a bad job. }\end{array}$ & 0 to 10 \\
\hline gov.explains.in.country & The government in [country] explains its decisions to voters. & 0 to 10 \\
\hline gov.responds.in.country & $\begin{array}{l}\text { Sometimes the government disagrees with what most people think is best for } \\
\text { the country. Which one of the statements on this card describes what you think } \\
\text { is best for democracy in general? } \\
\text { Using this card, please tell me how often you think the government in [country] } \\
\text { today sticks to its planned policies regardless of what most people think? OR } \\
\text { Using this card, please tell me how often you think the government in [country] } \\
\text { today changes its planned policies in response to what most people think? }\end{array}$ & $\begin{array}{l}0 \text { [never] to } 10 \\
\text { [always] } \\
0 \text { [never] to } 10 \\
\text { [always] } \\
\text { The two are } \\
\text { combined with the } \\
\text { first one inverted. }\end{array}$ \\
\hline free.extreme.views.in.country & $\begin{array}{l}\text { Using this card, to what extent do you think everyone in [country] today is free } \\
\text { to express their political views openly, even if they are extreme? OR } \\
\text { Using this card, to what extent do you think those who hold extreme political } \\
\text { views in [country] today are prevented from expressing them openly? }\end{array}$ & $\begin{array}{l}0 \text { to } 10 \\
\text { [completely] } \\
0 \quad 10 \\
\text { [completely] } \\
\text { The two are } \\
\text { combined with the } \\
\text { second } \\
\text { inverted. }\end{array}$ \\
\hline social.trust & $\begin{array}{l}\text { Using this card, generally speaking, would you say that most people can be } \\
\text { trusted, or that you can't be too careful in dealing with people? Please tell me } \\
\text { on a score of } 0 \text { to } 10 \text {, where } 0 \text { means you can't be too careful and } 10 \text { means } \\
\text { that most people can be trusted. }\end{array}$ & 0 to 10 \\
\hline feel.country.attached & How emotionally attached do you feel to [country]? & 0 to 10 \\
\hline justice.prevails & $\begin{array}{l}\text { There are many different views as to what makes a society fair or unfair. How } \\
\text { much do you agree or disagree with each of the following statements? I am } \\
\text { confident that justice always prevails over injustice. }\end{array}$ & $\begin{array}{l}1 \text { agree strongly } \\
\text { to } \\
5 \text { disagree strongly } \\
\text { Inverted! }\end{array}$ \\
\hline feel.pessimistic & $\begin{array}{l}\text { Using this card, please say how much you agree or disagree with each of the } \\
\text { following statements... I'm always optimistic about my future }\end{array}$ & $\begin{array}{l}1 \text { agree strongly } \\
\text { to } \\
5 \text { disagree strongly }\end{array}$ \\
\hline life.gets.better & .... The way things are now life is getting worse rather than better & 1 agree strongly \\
\hline
\end{tabular}




\begin{tabular}{|c|c|c|}
\hline & & $\begin{array}{l}\text { to } \\
5 \text { disagree strongly }\end{array}$ \\
\hline feel.hopefull & ... I find it hard to be hopeful about the future of the world & $\begin{array}{l}1 \text { agree strongly } \\
\text { to } \\
5 \text { disagree strongly }\end{array}$ \\
\hline feel.unsafe & $\begin{array}{l}\text { How safe do you - or would you - feel walking alone in this area after dark? Do } \\
\text { - or would - you feel... }\end{array}$ & $\begin{array}{l}1 \text { Very safe to } 4 \\
\text { Very unsafe }\end{array}$ \\
\hline feel.unhealthy & How is your health in general? Would you say it is ... & $\begin{array}{l}1 \text { Very good to } 5 \\
\text { Very bad }\end{array}$ \\
\hline feel.happy & Taking all things together, how happy would you say you are? & 0 to 10 \\
\hline life.satisfaction & All things considered, how satisfied are you with your life as a whole nowadays? & 0 to 10 \\
\hline place.in.society & $\begin{array}{l}\text { here are people who tend to be towards the top of our society and people who } \\
\text { tend to be towards the bottom. On this card there is a scale that runs from top } \\
\text { to bottom. Where would you place yourself on this scale nowadays? }\end{array}$ & $\begin{array}{l}0 \text { bottom } \\
\text { to } \\
10 \text { top }\end{array}$ \\
\hline $\operatorname{lr}$ & $\begin{array}{l}\text { In politics people sometimes talk of 'left' and 'right'. Using this card, where } \\
\text { would you place yourself on this scale, where } 0 \text { means the left and } 10 \text { means } \\
\text { the right? }\end{array}$ & 0 to 10 \\
\hline sat.government & $\begin{array}{l}\text { Now thinking about the [country] government, how satisfied are you with the } \\
\text { way it is doing its job? }\end{array}$ & 0 to 10 \\
\hline voters & $\begin{array}{l}\text { Some people don't vote nowadays for one reason or another. Did you vote in } \\
\text { the last [country] national election in [month/year]? }\end{array}$ & $\begin{array}{l}1 \text { yes, } 2 \text { no } \\
\text { Recoded to } 1 / 0\end{array}$ \\
\hline partisans & How close do you feel to this party? Do you feel that you are ... & $\begin{array}{l}1 \text { [very close] to } 4 \\
\text { [not at all close] } \\
\text { Recoded into } 1 \\
\text { or } 2 \text { ] } / 0 \text { [rest] }\end{array}$ \\
\hline
\end{tabular}




\section{Descriptive statistics}

Table A2. Descriptive statistics of the continuous variables used in the study

\begin{tabular}{lrrrrr} 
Variable & Min & Median & Mean & Max & St.Dev. \\
\hline sat.democracy & 0 & 5 & 5.1 & 10 & 2.6 \\
dem.evaluation & 0 & 6 & 6 & 10 & 2.5 \\
imp.democracy & 0 & 9 & 8.4 & 10 & 2.1 \\
imp.fair.elections & 0 & 10 & 9 & 10 & 1.7 \\
imp.dem.checks & 0 & 26 & 24.8 & 30 & 5.5 \\
imp.free.extreme.views & 0 & 1 & 0.7 & 1 & 0.4 \\
pol.efficacy & 1 & 11 & 10.8 & 25 & 3.9 \\
political.trust & 0 & 11 & 10.7 & 30 & 7 \\
trust.extra & 0 & 11 & 10.8 & 20 & 5.1 \\
pol.activism & 0 & 0 & 0.7 & 6 & 1.1 \\
pol.interest & 1 & 2 & 2.3 & 4 & 0.9 \\
pol.news & 0 & 2 & 2.2 & 7 & 1.7 \\
sat.policy & 0 & 15 & 15 & 30 & 6.3 \\
pol.transparent & 1 & 2 & 2.4 & 5 & 0.9 \\
gov.works.for.all & 1 & 3 & 2.5 & 5 & 0.9 \\
imp.gov.responds & 0 & 1 & 0.7 & 1 & 0.5 \\
fair.elections.in.country & 0 & 8 & 7 & 10 & 3 \\
dem.checks.in.country & 0 & 16 & 14.4 & 20 & 4.9 \\
gov.punished.in.country & 0 & 6 & 5.5 & 10 & 3.1 \\
gov.explains.in.country & 0 & 5 & 4.6 & 10 & 2.8 \\
gov.responds.in.country & 0 & 4 & 4 & 10 & 2.5 \\
free.extreme.views.in.country & 0 & 7 & 6.4 & 10 & 2.6 \\
social.trust & 0 & 5 & 4.9 & 10 & 2.5 \\
feel.country.attached & 0 & 8 & 7.8 & 10 & 2.2 \\
justice.prevails & 1 & 3 & 2.9 & 5 & 1.1 \\
feel.pessimistic & 1 & 2 & 2.3 & 5 & 1 \\
life.gets.better & 1 & 2 & 2.2 & 5 & 1 \\
feel.hopefull & 1 & 2 & 2.6 & 5 & 1.1 \\
feel.unsafe & 1 & 2 & 2 & 4 & 0.8 \\
feel.unhealthy & 1 & 2 & 2.2 & 5 & 0.9 \\
feel.happy & 0 & 8 & 7.2 & 10 & 2 \\
life.satisfaction & 0 & 7 & 6.9 & 10 & 2.3 \\
place.in.society & 0 & 5 & 5.4 & 10 & 1.9 \\
lr & 0 & 5 & 5.1 & 10 & 2.3 \\
lr.ex & 0 & 1 & 1.7 & 5 & 1.6 \\
sat.government & 0 & 4 & 4.1 & 10 & 2.6 \\
disproportionality & 0.7 & 6.1 & 7.5 & 17.8 & 5.1 \\
\hline
\end{tabular}




\section{Models including year random effects}

The figure below summarizes the results from multilevel models that include an interaction between the effect of winner status and year

Coefficients and $\mathbf{9 5 \%}$ confidence intervals for the effects of voting for a winning party for citizens in 2012 and 2018

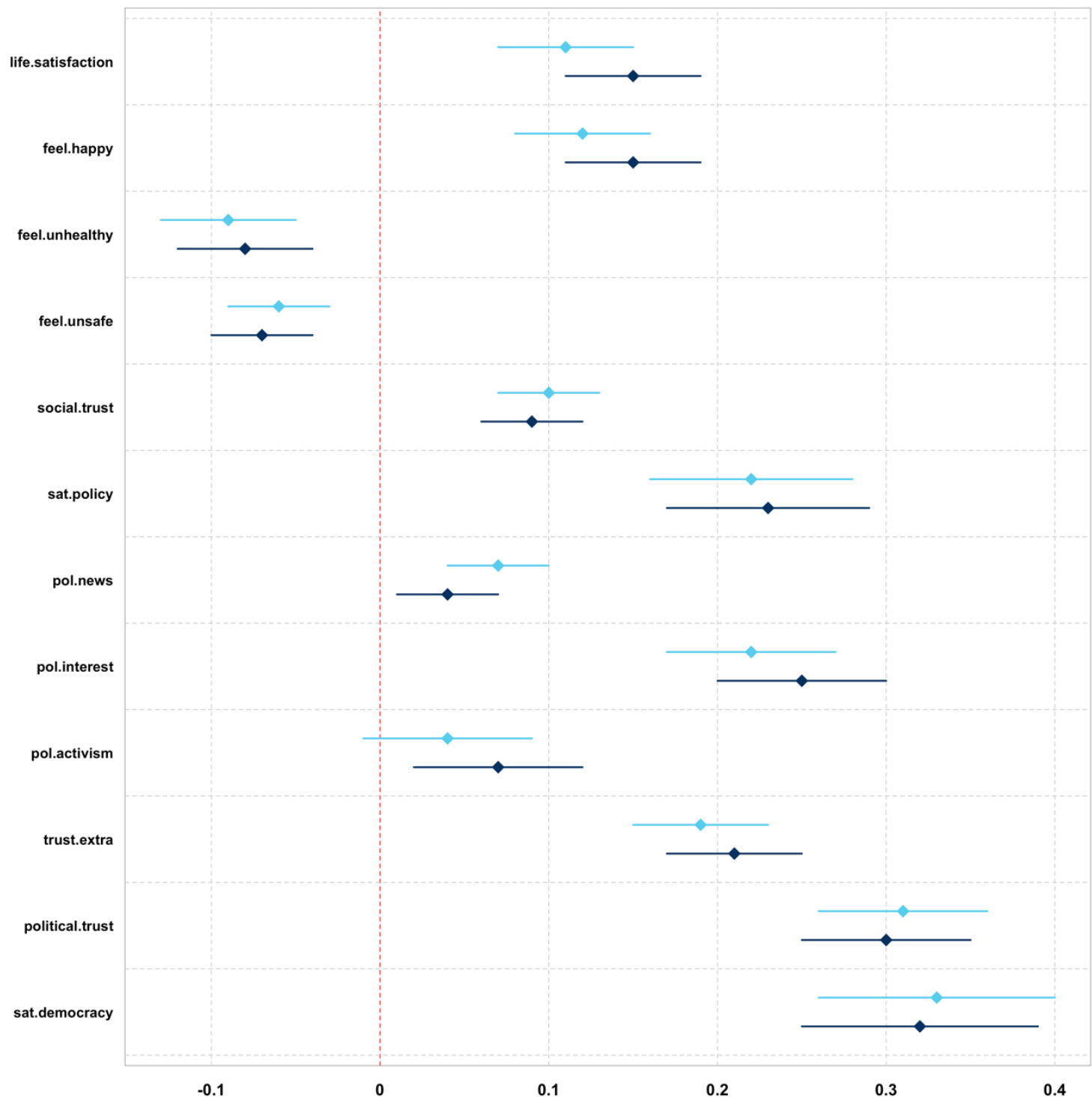

Figure A1. Coefficients and 95\% confidence intervals for the effects of voting for a winning party among citizens in 2012 and 2018 (for the variables included in both survey waves) 


\section{Formal causal mediation analysis}

The table below summarizes results from formal causal mediation analysis (Imai et al. 2010) conducted with the mediation package in $\mathrm{R}$ (Tingley et al. 2014). Winner status is the treatment, satisfaction with government is the mediator, and the equations for the mediator and the outcome are multilevel models that feature age, gender, education, employment, left-right position, extremity of the left-right position, and mixed intercepts and slopes for the winner status at the country level.

Table A3. Summary of causal mediation analyses. ACME - Average Causal Mediation Effect; ADE Average Direct Effect

\begin{tabular}{|c|c|c|c|c|c|c|c|c|}
\hline & Variable & ACME & p-value & $\mathrm{ADE}$ & p-value & Total effect & p-value & Prop. mediated \\
\hline 1 & sat.democracy & 0.76 & 0.00 & 0.05 & 0.38 & 0.81 & 0.00 & 0.94 \\
\hline 2 & dem.evaluation & 0.53 & 0.00 & 0.12 & 0.14 & 0.65 & 0.00 & 0.80 \\
\hline 3 & imp.democracy & 0.08 & 0.00 & 0.20 & 0.00 & 0.29 & 0.00 & 0.29 \\
\hline 4 & imp.fair.elections & -0.01 & 0.04 & 0.21 & 0.00 & 0.20 & 0.00 & -0.04 \\
\hline 5 & imp.dem.checks & -0.23 & 0.00 & 0.16 & 0.24 & -0.07 & 0.64 & 1.23 \\
\hline 6 & imp.free.extreme.views & -0.01 & 0.00 & 0.01 & 0.44 & -0.00 & 0.70 & 0.70 \\
\hline 7 & pol.efficacy & 0.48 & 0.00 & 0.35 & 0.00 & 0.84 & 0.00 & 0.57 \\
\hline 8 & political.trust & 1.92 & 0.00 & 0.00 & 0.94 & 1.92 & 0.00 & 1.00 \\
\hline 9 & trust.extra & 0.90 & 0.00 & 0.03 & 0.78 & 0.94 & 0.00 & 0.97 \\
\hline 10 & pol.activism & -0.04 & 0.00 & 0.08 & 0.00 & 0.04 & 0.02 & -1.07 \\
\hline 11 & pol.interest & 0.02 & 0.00 & 0.14 & 0.00 & 0.15 & 0.00 & 0.10 \\
\hline 12 & pol.news & 0.02 & 0.00 & 0.02 & 0.44 & 0.05 & 0.06 & 0.51 \\
\hline 13 & sat.policy & 1.56 & 0.00 & -0.34 & 0.08 & 1.21 & 0.00 & 1.29 \\
\hline 14 & pol.transparent & 0.21 & 0.00 & 0.03 & 0.34 & 0.24 & 0.00 & 0.89 \\
\hline 15 & gov.works.for.all & 0.24 & 0.00 & 0.05 & 0.02 & 0.29 & 0.00 & 0.83 \\
\hline 16 & imp.gov.responds & -0.04 & 0.00 & -0.03 & 0.00 & -0.07 & 0.00 & 0.58 \\
\hline 17 & fair.elections.in.country & 0.34 & 0.00 & 0.35 & 0.00 & 0.69 & 0.00 & 0.50 \\
\hline 18 & dem.checks.in.country & 0.35 & 0.00 & 0.56 & 0.00 & 0.91 & 0.00 & 0.39 \\
\hline 19 & gov.punished.in.country & 0.31 & 0.00 & 0.06 & 0.52 & 0.38 & 0.00 & 0.82 \\
\hline 20 & gov.explains.in.country & 0.52 & 0.00 & 0.08 & 0.26 & 0.61 & 0.00 & 0.85 \\
\hline
\end{tabular}




\begin{tabular}{|c|c|c|c|c|c|c|c|c|}
\hline 21 & gov.responds.in.country & 0.29 & 0.00 & -0.07 & 0.24 & 0.22 & 0.00 & 1.28 \\
\hline 22 & free.extreme.views.in.country & 0.18 & 0.00 & 0.16 & 0.00 & 0.34 & 0.00 & 0.51 \\
\hline 23 & social.trust & 0.23 & 0.00 & -0.04 & 0.46 & 0.20 & 0.00 & 1.18 \\
\hline 24 & feel.country.attached & 0.14 & 0.00 & 0.24 & 0.00 & 0.38 & 0.00 & 0.38 \\
\hline 25 & justice.prevails & 0.11 & 0.00 & -0.02 & 0.30 & 0.08 & 0.00 & 1.28 \\
\hline 26 & feel.pessimistic & -0.07 & 0.00 & -0.01 & 0.76 & -0.08 & 0.00 & 0.95 \\
\hline 27 & life.gets.better & 0.14 & 0.00 & 0.01 & 0.62 & 0.15 & 0.00 & 0.91 \\
\hline 28 & feel.hopefull & 0.10 & 0.00 & 0.02 & 0.10 & 0.13 & 0.00 & 0.81 \\
\hline 29 & feel.unsafe & -0.03 & 0.00 & -0.02 & 0.16 & -0.05 & 0.02 & 0.61 \\
\hline 30 & feel.unhealthy & -0.04 & 0.00 & -0.02 & 0.22 & -0.06 & 0.02 & 0.66 \\
\hline 31 & feel.happy & 0.18 & 0.00 & 0.03 & 0.30 & 0.22 & 0.00 & 0.85 \\
\hline 32 & life.satisfaction & 0.28 & 0.00 & -0.02 & 0.62 & 0.26 & 0.00 & 1.06 \\
\hline 33 & place.in.society & 0.14 & 0.00 & 0.05 & 0.30 & 0.19 & 0.00 & 0.73 \\
\hline
\end{tabular}

